\title{
Hudobnopsychologický profil rockovej opery Jesus Christ Superstar
}

\section{Zuzana Hubinská - Ivana Lacková - Dominika Sondorová}

\section{Úvod}

Fenomén Jesus Christ Superstar je svetoznáme dielo Andrewa Lloyda Webbera a Tima Ricea. V tomto roku (12. 10. 2021) si pripomíname 50. výročie od jeho prvého javiskového uvedenia. Zhudobnený príbeh rozpráva o posledných dňoch Ježiša Krista Nazaretského od príchodu do Jeruzalema až po jeho ukrižovanie. U poslucháčov dielo často vyvoláva otázku - ide o muzikál alebo rockovú operu? Niektorí nadšenci vyjadrujú nesúhlas s označením rocková opera, iní odmietajú označenie muzikál. Kým muzikál možno definovat’ ako druh hudobného divadla, ktorý spája hovorenú reč, spev a tanec, rocková opera je skôr súčasnou formou opery, teda druhom hudobného divadla, v ktorom sa využíva spev a tanec, ale nie hovorená reč. Rocková opera zároveň neuplatňuje prvky humoru a komiky tak ako muzikál, ale stavia na prvkoch vážnosti a prináša témy s hlbokou výpovednou hodnotou. Je tiež nutné zdôraznit', že hudobná zložka rockovej opery sa neobmedzuje len na využitie rockových hudobných prvkov. Využíva široké hudobné spektrum od vážnej hudby až po jednotlivé žánre súčasnej populárnej hudby ako je folk, pop a pod. ${ }^{1}$ Rocková opera je tiež charakteristická rytmickou pulzáciou, dynamickou naliehavostou a melodickostou, čím dokáže intenzívnym spôsobom sprostredkovat’ myšlienky a emócie poslucháčovi. Na základe týchto charakteristík možno dielo Jesus Christ Superstar označit ako rockovú operu. Rock je v súčasnosti jedným z najoblúbenejších žánrov populárnej hudby, ktorý vznikol koncom 50. rokov 20. storočia $v$ USA, pričom sa rýchlo rozšíril do celého sveta. ${ }^{2} \mathrm{~V} 60$. rokoch sa v rámci rocku formovali rozmanité hudobné štýly ako hard rock, blues rock, punk rock, heavy metal či progresívny rock, ktorý smeroval ku kompozičným štruktúram a využíval pestrý inštrumentálny, harmonický, rytmický a lyrický obsah alebo časté zmeny tempa a tóniny. ${ }^{3}$ Progresívny rock vyprodukoval širokú škálu obdivuhodných 
a pozoruhodných diel, medzi ktoré nepochybne patrí aj konceptuálny album Andrewa Lloyda Webbera a Tima Ricea Jesus Christ Superstar (1970).

\section{Okolnosti vzniku rockovej opery Jesus Christ Superstar}

Prvou úspešnou spoluprácou autorov rockovej opery Jesus Christ Superstar Andrewa Lloyda Webbera a Tima Ricea bolo biblické spracovanie príbehu o Jozefovi s názvom Joseph and his Amazing Technicolor Dreamcoat [Jozef a jeho zázračný pestrofarebný plášt']. Sprvoti pätnást'minútové oratórium sa postupne predlžovalo a ako výsledné hudobnodramatické dielo si získalo celosvetové uznanie. ${ }^{4}$ Reverenda Martina Sullivana zaujala popularita tohto oratória, a preto autorom ponúkol Katedrálu sv. Pavla v Londýne, v ktorej by mohli uviest’ svoje d’alšie spoločné dielo. Podmienkou však bolo zachovanie náboženského námetu. ${ }^{5} \mathrm{~T}$. Rice a A. L. Webber spočiatku plánovali spracovat' príbeh o Robinovi Hoodovi alebo J. F. Kennedym. 6 Sám reverend ich nabádal, aby ostali pri náboženskej tematike. Tvorcov nakoniec zaujal príbeh o posledných dňoch Ježiša Krista Nazaretského. ${ }^{7}$ Rozprávaný je však z pohl’adu Judáša lškariotského, ktorý v príbehu vystupoval ako pozorovatel' a komentátor Mesiášovej mučeníckej cesty. Tvorcovia sa sústredili na osobnost' Judáša, pretože v kanonických evanjeliách je o ňom málo zmienok. Aj napriek tomu sa autori pri tvorbe textov snažili čo najvernejšie reprodukovat' evanjeliá podla Matúša, Marka, Lukáša a Jána v snahe nebyt' príliš kontroverzní. K tomuto známemu príbehu pridali moderné popové mýty, ktoré opisovali situáciu a problémy slávnej osobnosti, Ježiša, na sklonku života. ${ }^{8} \mathrm{~V}$ prvom momente začali autori pracovat' na vytvorení dramatickej línie príbehu, následne začal A. L. Webber s kompozíciou a prácou na partitúre. T. Rice napísal svoje texty až úplne na koniec, na dodanú hudbu. ${ }^{9}$ Autori rockovej opery pridali postavám na autentickosti využitím súčasného slangu (apoštoli oslovovali Ježiša prezývkou J. C. - „džej sí) a usilovali sa zobrazit' ich ako obyčajných l'udí. Ježiš tak stratil svoju nadpozemskú auru a Judáš sa zbavil temperametnej povahy. ${ }^{10}$

Dielo Jesus Christ Superstar nebolo písané pre konkrétnych interpretov, čím sa stalo univerzálnym. Aj vd’aka tomu sa rýchlo rozšírilo do celého sveta a stalo sa fenoménom, ktorý tvorcovia zvečnili v mnohých divadelných inscenáciách a v dvoch filmových spracovaniach. ${ }^{11}$ Inscenačný klúč prvej divadelnej podoby rockovej opery Jesus Christ Superstar udal režisér Tom O'Horgan. Premiéra sa uskutočnila 12. októbra 1971 v divadle na Broadwayi. ${ }^{12}$ O'Horgan poňal rockovú operu ako oslnivú, okázalú extravagantnú show s mnohými efektmi. Rocková opera sa však po svojej premiére nevyhla nepríjemným ohlasom. Lloyd Webber a Rice nad’alej verili, že dielo dokáže prilákat’ aj ateistických divákov a zoznámi ich so životom Ježiša Krista, ku ktorému by sa inak pravdepodobne nedostali. Nasledovalo uvedenie v londýnskej štvrti West End (1972). Londýnska inscenácia rockovej opery Jesus Christ Superstar bola na prianie autorov vizuálne jednoduchšia. Režisérom inscenácie bol Jim Sharman. ${ }^{13}$ Toto dielo bolo atraktívne aj vd’aka skutočnosti, že Lloyd Webber využil témy vtedajšej doby a tiež aktuálny hudobný žáner. Náboženská tematika a symbolika slúžili ako známe a zrozumitelné prostredie, v ktorom autori predostreli závažné problémy mladých ludí, ale aj ludstva všeobecne. Prvá filmová verzia vznikla v roku 1973 (jej režisérom bol Norman Jewison) a druhé filmové spracovanie pochádza z roku 2000 v réžii Gala Edwardsa a Nicka Morrisa. 


\section{Dej rockovej opery Jesus Christ Superstar}

Rockovú operu otvára ouvertúra. Po jej doznení prichádza Judáš, ktorý sa prihovára Ježišovi ešte predtým, než spolu s ostatnými učeníkmi prichádza do Bretánie. V piesni Heaven On Their Minds [Už nie som zmámený] ${ }^{14}$ sa Judáš stretáva s Ježišom a príkro ho obviňuje, že vo svojom pôsobení zašiel prid’aleko. Z mesta sa vracajú apoštoli a s údivom sledujú, ako Judáš útočí na Ježiša. V piesni What's The Buzz [Čo to je?] ${ }^{15}$ sa pýtajú, čo sa to deje. Ježiša žiadajú, aby spoločne ovládli Jeruzalem. Vtom prichádza Mária Magdaléna, ktorá chce Ježiša upokojit’ a začne mu natierat’ nohy vonnou mast’ou. To Judáša ešte viac nahnevá a začne sa s Ježišom hádat’ o zmysle hriechu a odpustení. Neoblomná Mária Magdaléna aj napriek urážkam zotrváva pri Ježišovi a spieva Everything's Alright [Nič zlé ti nehrozí]. ${ }^{16}$ Medzitým sa stretnú vel'kňazi Annáš a Kaifáš s d’alšími židovskými kňazmi. V piesni This Jesus Must Die [Smrt' podstúpit' má!] ${ }^{17}$ spoločne vymýšl'ajú plán, ako Ježiša zatknút' a umlčat'. Obávajú sa jeho narastajúcej popularity a vplyvu na spoločnost'. Ježiš prichádza do Jeruzalema a nadšený dav ho ospevuje (pieseň Hosanna). Z davu vystúpi apoštol Šimon, ktorý začne Ježiša nabádat', aby sa ujal vlády a viedol židovský národ do povstania proti Rimanom. Ten to odmieta a v piesni Poor Jerusalem [Úbohý Jeruzalem] ${ }^{18}$ rozpráva o neporozumení jeho učenia. Dej sa presúva k Pilátovi, ktorý vo svojej piesni Pilate's Dream [Pilátov sen] ${ }^{19}$ opisuje znepokojujúci sen o Ježišovom príchode a jeho vražde. Nasleduje scéna - The Temple [Chrám]. ${ }^{20}$ Na nádvorí chrámu sa zhromaždili predavači a komedianti. Pribieha Ježiš a v hneve rozhádže predavačom stoly a všetkých vyháňa. Vtom k nemu prichádza skupina malomocných a žiada ho, aby ich vyliečil. Je ich vela a Ježiš nemá dostatok sily na ich uzdravenie, preto ich odháňa preč slovami: „Uzdravte sa sami“. ${ }^{21}$ Opät prichádza Mária Magdaléna a s motívom piesne Everything's Alright [Nič zlé ti nehrozí] ${ }^{22}$ uloží vyčerpaného Ježiša spat'. Táto scéna plynulo prechádza do piesne I Don't Know How To Love Him [Chcem hriat' ho svojou láskou], ${ }^{23}$ v ktorej sa Mária spovedá zo svojich citov, konkrétne z lásky, ktorú k Ježišovi cíti. Judáš sa pod hrozbou rímskej okupačnej moci rozhodne Ježiša zradit', aby zachránil židovský národ - pieseň Damned For All Time / Blood Money [Nie som podlý / Krvavé prachy]. ${ }^{24}$ Prvé dejstvo sa končí príchodom Judáša, ktorý od vel'kňazov prijíma peniaze za zradu Ježiša.

Druhé dejstvo otvára pieseň The Last Supper [Posledná večera]..$^{25}$ Apoštoli sa s Ježišom stretajú na spoločnej večeri. Kristus im odovzdáva chlieb - svoje Telo a víno - svoju Krv. Predpovedá, že dvaja z apoštolov ho zradia: Peter, ktorý tomu nechce uverit', a Judáš, ktorý zradu už istý čas chystá. Judášove úmysly sa ukázali v plnej nahote a zradca prechádza do protiútoku. Apoštoli vystúpili spolu s Ježišom do Getsemanskej záhrady na Olivovej hore, aby Ježiš neostal pred udalostami, ktoré mali príst', opustený. Apoštoli však pospia a Ježiš osamie: vo svojom vnútri zápasí medzi strachom zo smrti a vôlou prijatím smrti splnit’ Boží plán. Zaznieva pieseň Gethsemane / I Only Want To Say [Getsemanská záhrada / Chcem len povedat']. ${ }^{26}$ Prichádzajú židovskí kňazi, rímski vojaci a Judáš. Ten bozkom prezradí Kristovu identitu. Peter sa pokúsi Krista chránit’ mečom, ale ten mu to nedovolí. Odvádzajú ho do zajatia a apoštoli sa v strachu rozpŕchnu. Peter zaprie Ježiša v piesni Peter's Denial [Petrovo zapretie]. ${ }^{27}$ Krista predviedli pred Piláta. Ten nevidí dôvod, prečo by mal byt' Ježiš potrestaný. Posiela ho za král'om Herodesom. Ten v piesni King Herod's Song [Herodesova pieseň] ${ }^{28}$ žiada Ježiša, aby mu ukázal nejaký zázrak a tým potvrdil svoju výnimočnost'. Zázrak sa však neudeje a rozčúlený král' posiela Ježiša spät' za Pilátom. Na scénu prichádza Mária Magdaléna spolu s apoštolmi 
a zaznieva pieseň Could We Start Again, Please? [Ved' nás pravou cestou]. ${ }^{29}$ Spoločne prosia Boha, aby im ukázal, čo majú robit'. Následne sa objavuje Judáš, ktorý kňazom vyčíta ich krutost' $\mathrm{k}$ Ježišovi. Pod nátlakom vlastného zúfalstva a výčitiek svedomia spácha počas piesne Juda's Death [Judášova smrt'] ${ }^{30}$ samovraždu. Opät’ sa pozornost obráti na Ježiša, ktorý stojí pred Pilátom. V piesni Trial By Pilate [Pilátov súd] ${ }^{31}$ žiada Kaifáš spolu s rozvášneným davom Ježišovu smrt'. Pilát cíti, že Ježiš nespravil nič zlé a nechce podlahnút nátlaku, preto ho na upokojenie dá 39-krát zbičovat'. Dav sa však neupokojí, Pilát žiada od Ježiša argument, aby ho nemusel poslat' na smrt'. Ježiš však odpovedá: „Nie je v tvojich silách niečo zmenit!'³2 Pilát je preto nútený odsúdit' ho na smrt'. Ježišovi naložili kríž, ktorý vlečie na miesto popravy. Cestou ho stretá Satan, ktorý sa nápadne podobá na Judáša. Počas piesne Superstar sa vysmieva Ježišovi, že jeho obeta je len prázdnym gestom - ved' ludia budú aj nad’alej hrešit'. Ježišovo utrpenie kulminuje. Pribíjajú ho na kríž - a zomiera. Satanov hlas doznel. Odkrýva sa skutočný význam obety.

\section{Charakterizácia postáv rockovej opery Jesus Christ Superstar}

Ježiš Kristus - rôznymi náboženstvami označovaný za proroka, mesiáša, spasitelá l'udstva, ktorý hlásal príchod Božieho královstva a vyzýval národ k pokániu

Meno Ježiš pochádza z gréckeho mena lésus, ktoré sa v gréckej Septuaginte uvádza ako prepis hebrejského mena Jehošua alebo skrátene Ješua (Jahve je spasenie, Spasitel', Záchranca). Ježiš bol často označovaný aj Ježiš Nazaretský alebo Ježiš z Nazaretu, krest’ania používali titul Ježiš Kristus. Tento titul pochádza z gréckeho christós - pomazaný, uvádza sa tiež, že toto slovo je prekladom hebrejského Mesiáš - „pomazaný Jahvem“, resp. „pomazaný Bohom“. V Biblii sa Ježiš Kristus spomína v štyroch evanjeliách uvedených v Novom zákone ako židovský učitel' kázajúci evanjelium, ktorý uzdravoval chorých a vyháňal zlo z l'udí prostredníctvom sily Ducha Svätého. ${ }^{33}$

Konkrétny dátum narodenia Ježiša Krista bol neznámy, od roku 336 v Ríme bolo po prvýkrát doložené jeho narodenie 25. decembra. Jeho život možno rozdelit’ do troch období. Prvá epocha sa začala dávno pred Ježišovým narodením, ked'sa Boh stal Stvoritelom. V Biblii je Ježiš opisovaný ako prvorodený syn (Jn 1: 14). Ďalšia epocha sa odohrávala na zemi. Jeho život sa začal zázrakom, ked'Duch svätý spočinul na vernej židovskej panne Márii (Lk 1: 34, 35). Jeho pozemským otcom bol tesár Jozef (Iz 7: 14, Mt 1: 22, 23, Mk 6: 3). ${ }^{34}$ Ježiš sa narodil v Betleheme. Správa o jeho narodení sa dostala až ku král'ovi Herodesovi Vel'kému, ktorý zo strachu prikázal pozabíjat všetky deti v Betleheme. Jozefa však v sne varoval archanjel Michal, a tak rodina utiekla do Egypta. ${ }^{35}$ Po návrate z Egypta spoločne žili v Nazarete. O Ježišovom detstve a dospievaní sa však všeobecne vie vel'mi málo. Jeho nová cesta a verejné vystupovanie sa začali, ked’ ho Ján pokrstil v Jordáne. Odvtedy hlásal, že je Božím synom. Tieto slová dokladal viacerými skutkami, ktoré sa označujú ako zázraky prevyšujúce bežné ludské schopnosti (voda premenená na víno, uzdravovanie chorých a pod.). Viaceré evanjeliá ho opisujú ako vrúcneho človeka, ktorý bol k druhým vel'mi láskavý a úctivý. Povolával aj svojich prvých učeníkov - dvanástich apoštolov. Medzi jeho učenie patrí napríklad blahoslavenstvo, vyzývanie ku konaniu 
dobrých skutkov a tiež výzva milovat’ blížnych tak ako seba. Svojich učeníkov tiež učil, ako sa majú modlit', aby mohli po jeho smrti (ktorú sám predpovedal) d’alej šírit jeho učenie. Predpovedal aj d’alšie znamenia, ktoré budú viest' k jeho smrti ako napríklad, že ho jeden z apoštolov, Judáš Iškariotský, zradí. Na Olivovej hore ho preto zajali a predviedli pred veliradu a následne pred Piláta. ${ }^{36}$ Zomrel na Golgote ako mučeník, nevinne zbičovaný a odsúdený Pontským Pilátom na žiadost' židovskej vel'rady. Na tretí deň však vstal z mítvych a stal sa duchovnou bytostou. ${ }^{37} \mathrm{~V}$ tomto momente sa začína tretia etapa jeho života. Viackrát sa podla svedectva zjavil l'ud’om žijúcim v prvom storočí nášho letopočtu a na 40. deň od svojej smrti vystúpil na nebesia a usadil sa po Božej pravici. Po tzv. Armagedone (konci sveta) budú jeho nasledovníci žit’ navždy spolu s Bohom a Ježišom Kristom v nebeskom Královstve (Zjavenie 7: 9, 14, 16, 21: 3,4). ${ }^{38}$ Vyobrazenie Ježiša Krista v iných príbehoch je často konfrontované s predstavami vychádzajúcimi z Biblie. Základným znakom tohto mýtu je Ježišova zdvojená podstata - l'udská a božská -, ktorá je často predmetom nielen teologických úvah, ale aj výraznou dramatickou inšpiráciou pre viacerých umelcov. Životný príbeh Ježiša Krista pritiahol napríklad aj autorov rockovej opery A. L. Webbera a T. Ricea. ${ }^{39}$

\section{Ježiš Kristus v rockovej opere Jesus Christ Superstar}

Kristus je ústrednou postavou mýtického príbehu, na základe ktorého stojí krestanské náboženstvo. Tvorcovia diela sa usilovali predostriet' príbeh Ježiša Krista nie ako Boha, ale ako človeka/muža. Lloyd Webber v jednom z mnohých rozhovorov uvádza, že Ježiš sa nikdy nepovažoval za Boha, ale za jeho syna. Ani v diele samotnom sa zámerne nerozoberá, či Ježiš je, alebo nie je Bohom. Odpoved' na túto otázku ostáva otvorená.

Ježiš Kristus bol prezentovaný ako obyčajný človek. Na jednej strane to bol láskavý, citlivý muž, ktorému záleží na svojich blízkych a hlása lásku k druhým. Jeho vlúdnost’ sa prejavovala vo vzt’ahu k celému národu, ale najmä k Márii Magdaléne, ktorú aj napriek jej zlej povesti vždy obraňoval. Vd’aka jeho dobrosrdečnosti ho dav obdivoval, čo sa ukázalo aj pri vstupe do Jeruzalema. Vedel však prejavit’ aj negatívne emócie.40 Pochyboval o zmysle svojej cesty, ukázal strach a priznal Bohu svoju slabost'. Bál sa svojej smrti, uvedomoval si však, že nemôže vzdorovat' božej vôli. ${ }^{41} \mathrm{~V}$ momente svojej smrti žiada o milost' pre l'udí, ktorí ho odsúdili na smrt"2 - „God forgive them. They don't know what they're doing ${ }^{\prime \prime 3}$ [Otče, odpust' im. Lebo nevedia, čo robia.]. ${ }^{44}$

Po celú dobu zhudobneného príbehu je Ježiš považovaný za hviezdu - Superstar. ${ }^{45}$ Nelíši sa od ostatných ludí, nie je zosobnením božstva, avšak jeho vzrastajúca popularita mu otvára rôzne príležitosti stat' sa vodcom a vyviest' svoj lud spod nadvlády rímskych uchvatitelov. Svoju slávu môže upevnit’ a premenit' ju na moc. Túto príležitost', podobne ako d’alšie, ktoré mohli zmenit' jeho život, nevyužil a odovzdal sa predurčenému osudu. ${ }^{46}$ Ježiš Kristus predstavuje skôr obraz a pamiatku márnych obetí, než príklad revolucionára a vodcu. ${ }^{47}$

\section{Judáš Iškariotský - kontroverzná osobnost' krestáanských dejín}

Judáš lškariotský je jednou z najzáhadnejších postáv Biblie. Bol učeníkom a jedným z dvanástich apoštolov Ježiša Krista. Vd’aka svojej povestnej úlohe vo všetkých evanjeliách zostáva Judáš kontroverznou osobnost’ou krestanských dejín. Jeho meno je dodnes známe ako symbol zrady, zloby a zákerného konania. Aj v umení sa Judáš etab- 
loval ako synonymum neviery, chamtivosti, zrady, podvratnej činnosti a ludskej podlosti. O jeho pôvode existuje minimum informácií. V apokryfe z 12. storočia Rozprávanie Jozefa Arimatejského sa tvrdí, že Judáš bol synom Kajfášovo brata. Ide však o nepotvrdenú mienku. Iba Ján spomína, že je synom Šimona Iškariotského. ${ }^{48}$ Judáš mal na starosti spoločné peniaze apoštolov, z ktorých často financoval svoje vlastné túžby a aktivity. Mnoho teológov je presvedčených, že láska k peniazom Judáša negatívne formovala od detstva. Pravdepodobne už v mladosti páchal malé krádeže. Ján vo svojom evanjeliu opisuje, ako bol Judáš prekvapený, ked’ Mária Magdaléna pomazala vzácnym olejom Ježišove nohy, namiesto toho, aby olej predala a peniaze poskytla chudobným. ${ }^{49}$

Judáš mal iné predstavy o Ježišovi. Aj ked' ho spočiatku Kristove slová zaujali, jeho viera nebola pevná. Odmietol jeho lásku a ponuku spásy. Pri poslednej večeri Ježiš Kristus predpovedal, že ho Judáš zradí za tridsat’ strieborných židovskej vel'rade. Táto predpoved' sa naplnila a Judáš v Getsemanskej záhrade označil Ježiša Krista tým, že ho pobozkal. Ked' videl, že Ježiša odsúdili na smrt', trýznilo ho svedomie za to, že ho zradil. Vzal tridsat' strieborných, ktoré dostal za zradu, a vrátil ich vel'kňazom a židovským vodcom so slovami: „Zhrešil som, lebo som zradil nevinnú krv." Tí však odmietli peniaze pošpinené krvou nevinného. Judáš v zúfalstve odhodil peniaze na chrámovú dlažbu, vybehol z mesta a obesil sa na suchom strome. ${ }^{50}$

Motívy Judášovej zrady nie sú známe. Marek uvádza, že Judáš zradil Ježiša (Mk 14: 10 - 11) bez toho, aby naznačil motívy svojho konania. Podla Matúša (Mt 26: 15) sa Judáš dopustil zrady výmenou za tridsat' strieborných. Vo svojom výklade zdôrazňuje rolu peňazí a poukazuje na Judášovu lakomost'. Ján obvinenia stupňuje a označuje Judáša za lakomca a zlodeja. Lukáš naopak nachádza v zrade démonické pozadie (Lk 22: 3 - 5). Judáša vykresl'uje ako človeka, ktorého hnal k jeho skutku diabol. Zrada Judáša sa stala aj apologetickým problémom. Grécky filozof Celsus vo svojom spise Pravdivá doktrína uviedol, že jeden z učeníkov zradil Ježiša. Origenés, najvýznamnejší predstavitel' alexandrijskej školy, zastával myšlienku, že Judáš úplne nezradil Ježiša a jeho konanie vykazuje dvojznačnost'. Zároveň poukázal na to, že Judáš nebol explicitne zápornou postavou, pretože v ňom ostalo niečo z Ježišovho posolstva.

V minulosti prevládal názor, že Judáš zradil z pýchy a ctižiadostivosti. Tento symbol chamtivosti a zrady sa v súčasnosti neposudzuje tak jednoznačne. Objavujú sa aj nové pokusy o interpretáciu jeho príbehu. ${ }^{51}$ Muzikál Jesus Christ Superstar sa pozeral na udalosti práve z pohladu Judáša. ${ }^{52}$

\section{Judáš v rockovej opere Jesus Christ Superstar}

Judáš lškariotský, muž, ktorý zradil Ježiša zo sebeckých dôvodov a v konečnom dôsledku spôsobil dočasný pád Mesiáša, je v rockovej opere Jesus Christ Superstar zobrazený ako sympatický hrdina, ktorý konal z čestných dôvodov. Je zaujímavé, že Ježiš nie je ústrednou postavou tohto príbehu. Ten, kto riadi dej, je v skutočnosti Judáš. Lloyd Webber a Rice, či už úmyselne alebo nie, posunuli zmysel príbehu tak, aby bol videný skôr sekulárnou optikou. Dej je neustále nasmerovaný na Judášov konflikt. Judáš verí, že Ježiš nie je Boží Syn, a preto ako ústredná postava príbehu nakoniec prinúti divákov vidiet' Ježiša tak, ako ho vidí on. ${ }^{53}$ Svoj kritický postoj vysvetl'uje už v prvej piesni - Heaven On Their Minds [Už nie som zmámený]. ${ }^{54}$ Ježiša vníma ako osobu, ktorá premrhala všetok svoj potenciál. ${ }^{55}$ Vyjadruje svoje znepokojenie nad jeho rastúcou popularitou a poukazuje na jej negatívne dopady. Súčasne sa obáva, že Ježišova sláva môže byt' 
Rímskou ríšou chápaná ako hrozba ${ }^{56}$ _ „I am frightened by the crowd, for we are getting much too loud, and they'll crush us if we go too far, if we go too far."157 [Ak sa začne búrit' dav, ak vzplanie príliš vel’a hláv, celý národ bude zničený. Bude spálený!]. ${ }^{58}$ Vedel, že sa ludia pomstia tým, ktorí v nich vzbudia privel'ké očakávania. ${ }^{59}$ Veril, že svet zabudne na všetky dobré veci, ktoré Ježiš vo svojom živote vykonal a bude si ho namiesto toho pamätat’ ako obyčajného povstalca - muža, ktorý zničil Jeruzalem a priviedol Židov spät’ do otroctva. ${ }^{60}$ Aj preto Ježiša odhováral od cesty do Jeruzalema.

Judáš často spochybňoval l'ahkomyselné činy ludí okolo seba. Nebol nadšený ani prítomnostou Márie Magdalény (ženy so zlou povest’ou) v ich kolektíve. ${ }^{61}$ Vyčítal jej, že používa mast’ pre Ježiša namiesto toho, aby ju dávala chudobným. V Evanjeliu podla Jána vzala Mária Magdaléna libru vzácnej pravej nardovej masti a natrela ňou Ježišovi nohy a poutierala ich vlasmi. V tomto skutku bola akási predtucha Ježišovej smrti. ${ }^{62}$ Avšak jeden z jeho učeníkov, Judáš Iškariotský, ktorý ho mal zradit’, povedal: „Prečo túto mast' nepredali za tristo denárov a nedali ich chudobným?" Ale ako evanjelista dodáva: nešlo mu o chudobných. ${ }^{63} \mathrm{~V}$ diele Jesus Christ Superstar sa podla Judáša Ježiš nestará o chudobných a užíva si túto chvílu. Vyčíta mu náklonnost’ k Márii Magdaléne, s ktorou sa Judáš nemôže vyrovnat'. ${ }^{4}$ Judášovo správanie podmieňuje jednak to, že je zvnútra už akoby nahlodané jedom svojho predurčenia, ale aj vedomie toho, že Kristovu priazeň, takú ako by si on predstavoval, už nikdy nezíska. ${ }^{65}$

Navyše uchopenie Judáša nie ako zradcu vyvracia posolstvo, ktoré ponúka Biblia. V Biblii sa uvádza, že Judáš zradí Ježiša v dôsledku satanovho vplyvu. Dopustil sa zlého činu a jeho konanie je neospravedInitel'né. V diele Jesus Christ Superstar Judáš zrádza Ježiša, pretože sa cíti byt' podvedený. ${ }^{66}$ Svoje konanie sa snaží obhájit' nielen pred sebou, ale aj pred členmi náboženskej rady. Vel'kňazi žiadajú Judáša, aby im oznámil miesto, kde sa Ježiš zdržiava. Judášovi sú výmenou za informácie ponúkané peniaze. Judáš ich nechce prijat' - „I don't want your blood money! I don't need your blood money!" ${ }^{167}$ [Nie, nie, nechcem tie prachy! Nechcem krvavé prachy! ] ${ }^{68}$. Vel'kňazi ho však presvedčia - "Think of the things you could do with that money, Choose any charity - give to the poor. This is not blood money - it's a ... A fee. A fee nothing more." ${ }^{119}$ [Venuj ich biednym, ak máš s nimi problém. Mat' tol'ko peňazí kdekto by chcel.] ]0 Nad ránom Judáš privedie do Getsemanskej záhrady vojakov, ktorí majú Krista zatknút’ a odviest’ pred členov náboženskej rady. Vydesí ho, ako hrubo zaobchádzajú s Ježišom. Začína panikárit’ a cíti sa byt’ za všetko vinný. Svoj čin l'utuje a vracia krvavé peniaze. ${ }^{71}$ Uvedomuje si, že v tomto svete už nikdy nenájde pokoj: "My mind is in your hands now. My God, I am sick. I've been used. And you knew all the time. God! I'll never ever know. Why you chose me for your crime. Your

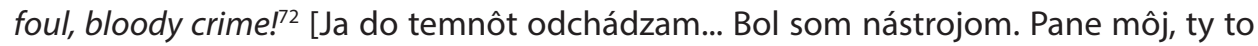
vieš. Prečo ja? Ach! Ty, pane, ty to vieš! Ach! Prečo ja?! Tú krv z rúk už nezmyješ!]. ${ }^{73} \mathrm{~V}$ tú chvílu mu akási vyššia sila stavia do cesty strom, na ktorom sa Judáš obesí a ukončí tak svoje trápenie. Z posledných síl ešte vyriekne svoje slová adresované Bohu: „You have murdered me! ${ }^{174}\left[\right.$ [Ty ma zabíjaš, zabíjaš, zabíjaš...]. ${ }^{75}$

V závere rockovej opery je Judáš postavený do pozície diváka, ktorý chce poznat’ odpovede na najzložitejšie otázky, s ktorými sa veriaci v modernom svete stretávajú. ${ }^{76}$ Vyčíta Ježišovi, že mohol všetko lepšie zariadit', vybrat’ si lepšiu dobu a krajinu. Dodáva, že dnes by si prostredníctvom masmédií získal celé národy. ${ }^{77}$ Príbeh sa končí Ježišovou smrtou, pretože Judáš už nežije. Judáš nevidí vzkriesenie, ani prvotnú cirkev. Nevie, že Ježiš a jeho učenie mali dlhodobý vplyv na svet. 
Mária Magdaléna - oddaná nasledovníčka Ježiša Krista

Mária Magdaléna je biblická svätica. Po Panne Márii druhá najčastejšie spomínaná osoba vo všetkých štyroch evanjeliách. ${ }^{78}$ Narodila sa v rybárskom mestečku Magdala, ktoré sa nachádza na západnom brehu Galilejského jazera (Izrael). ${ }^{79}$ Krestáanská tradícia ju od konca 6. storočia označovala za hriešnicu. Jej prvé stretnutie s Ježišom Kristom sa odohralo v čase, ked'bola v zlom duševnom a telesnom rozpoložení. Kristus Márii Magdaléne však vd’aka prejavom lásky a dobroty mnohé hriechy odpustil. Táto udalost’ bola spájaná s aktom vyhnania siedmich zlých duchov z Márie Magdalény ${ }^{80}$ - niektorí teológovia týchto „démonov" spájajú so siedmimi smrtelnými hriechmi. ${ }^{81}$ Po tomto obrátení sa stala jedným z Ježišových učeníkov, pravidelne sa zdržiavala v skupine žien, ktoré Ježišovi pomáhali. Sprevádzala ho na jeho krížovej ceste, pri jeho mučení a ukrižovaní.

Po Ježišovej smrti ho galilejské ženy spolu s Máriou Magdalénou pomazali mastami a zavinutého v plátne odniesli do skalného hrobu. $O$ tri dni sa k hrobu vrátili, aby zabalzamovali Ježiša. Evanjelista Marek uvádza: „Ked’sa pominula sobota, Mária Magdaléna a Mária, matka Jakubova, i Salome nakúpili voňaviek, aby ho mohli íst' pomazat" (Mk 16: 1). Cestou k hrobu rozmýšlali nad tým, kto im pomôže odvalit’ tažký kameň, ale po príchode zistili, že hrob je prázdny. "Prišla ešte za tmy k hrobu a zbadala, že kameň je odvalený. Bežala teda k Šimonovi Petrovi a tomu d’alšiemu učeníkovi, ktorého Ježiš miloval, a hovorí im: Vzali Pána z hrobu a nevieme, kde ho uložili. Peter a ten d’alší učeník sa teda pobrali k hrobu." (Jn 20: 1 - 3). ${ }^{82}$ Po odchode apoštolov sa Mária Magdaléna ocitne sama pri hrobe. Vtedy za ňou prichádza muž a pýta sa jej prečo plače. Odpovedala mu „Pane, ak si ho ty odniesol, povedz mi, kam si ho položil a ja si ho vezmem!" (Jn 20: 11). Ked' ju oslovil jej menom, spoznala, že je to zmŕtvychvstalý Ježiš. Stala sa tak prvým človekom, ktorý zvestoval ostatným apoštolom, že Ježiš žije. ${ }^{83}$

O jej d’alšom živote je málo zmienok. Predpokladá sa, že istý čas spolupracovala s apoštolmi. Neskôr podla legiend odišla z Jeruzalema do Efezu (Malá Ázia), kde zomrela a bola pochovaná (neskôr jej ostatky preniesli do Carihradu). Jej verná láska opisovaná v evanjeliách je pre veriacich príkladom vernosti k Ježišovi Kristovi. ${ }^{84}$

\section{Mária Magdaléna v rockovej opere Jesus Christ Superstar}

Mária Magdaléna je v rockovej opere Jesus Christ Superstar jedinou ženskou postavou, preto zastáva ústrednú ženskú úlohu. ${ }^{85}$ Táto skutočnost’ v mnohých kritikách vyvolala rozpor. Mnohí veriaci medzi Ježišom a Máriou Magdalénou nachádzali sexuálny podtext, k čomu sa tvorcovia A. L. Webber a T. Rice vyjadrili slovami „Iba hlupák alebo gorila mohol povedat', že Kristus a Mária mali pomer. ${ }^{186}$ Toto vyhlásenie dosvedčujú aj slová z piesne I Don't Know How to Love Him ${ }^{87}$ [Chcem hriat' ho svojou láskou]: „Yet if he said he loved me / I'd be lost, l'd be frightended" ${ }^{\prime \prime 8}$ [Napriek tomu, ak by povedal, že ma miluje. Bola by som stratená, bála by som sa.]. ${ }^{89}$

Mária Magdaléna v diele zosobňovala oddanú Ježišovu nasledovníčku, cítila k nemu náklonnost’ a dôveru. ${ }^{90}$ Vd’aka svojej neoblomnosti a vytrvalej viere vystupovala ako tá, ktorá vždy Ježiša, ale i d’alších členov jeho sprievodu upokojovala, či dokonca zmierňovala ich hnev. ${ }^{91} \mathrm{~V}$ piesni What's The Buzz ${ }^{92}$ [Čo to je?] ${ }^{93}$ Judáš označuje Máriu Magdalénu ako padlú ženu. Ježiš sa jej však zastáva. Počas svojich výstupov Mária Magdaléna prejavovala empatiu, stabilitu, ale aj slabost'. Bola jedinou postavou, ktorá do vypätých situácií prinášala pokoj. ${ }^{94}$ 
Pri Márii Magdaléne tvorcovia narazili na niekol'ko nejasností, a preto mohli slobodnejšie pracovat’ na vykreslení jej charakteru, a teda aj na vzt’ahu k Ježišovi. V Evanjeliu podla Marka sa spomína žena, ktorá vyliala Ježišovi na hlavu vzácne oleje, čo vyvolalo konflikt medzi jeho nasledovníkmi, ktorí tento čin označili ako plytvanie drahocennost’ami pre chudobných. Ježiš sa vtedy ženy zastal, nikde sa však konkrétne nespomína, kto bola tá žena, ani sa neuvádza jej meno. V Evanjeliu podla Jána sa spomína, že to bola práve Mária Magdaléna, ktorá potrela Ježišovi nohy vonným olejom. Evanjelium podla Matúša sa problematike s vonnými mastami a olejmi úplne vyhýba (chýba v ňom tiež scéna s Herodesom). ${ }^{95}$ Väčšina nepochopenia vztahu Ježiša a Márie Magdalény vychádzala práve z nesprávnej interpretácie jej lásky k Ježišovej osobe. Ich spojenie nemuselo byt' založené na fyzickej prít’ažlivosti. Herečka Jo Lampert, ktorá stvárnila Máriu Magdalénu v obnovenom predstavení v roku 2018 (Lyric Opera of Chicago), si Máriin charakter vysvetl'uje nasledovne: Veta „I've had so many men before, ${ }^{\prime \prime 96}$ [Spravil zo mňa inú, zmývam špinu. Túžim byt' len s ním.] ${ }^{97}$ nemusí znamenat', že s nimi mala pomer. Ženy v tých časoch totiž nemohli kupovat'pôdu bez muža, ani nič vlastnit'. Pod týmito slovami možno chápat', že sa stretávala s bratmi."98 Mária Magdaléna bola zobrazením hlbokej oddanosti a lásky k Ježišovi. ${ }^{99}$

Pontský Pilát - muž, ktorý vstúpil do dejín tým, že odsúdil Ježiša Krista Historická postava Piláta, mnohými označovaného za krutého tyrana a nepriatela židovského národa, je dodnes predmetom úvah. Niektorí ho považujú za obet', pre iných je symbolom l'udskej slabosti. Zmienky o jeho osobe môžeme nájst' v kánonických či apokryfných evanjeliách, alebo u Jozefa Flavia a Filóna Alexandrijského. Dátum Pilátovho narodenia, ako aj dátum úmrtia, nie sú presne známe. Podla niektorých prameňov pochádzal zo Španielska, ale jeho meno naznačuje, že patril k rodu Pontiovcov (samnitskí šlachtici) z južného Talianska. ${ }^{100}$ Roku 26 n. I. ho rímsky cisár Tiberius (vládol v rokoch 14 - 37 n. I.) vymenoval za prefekta malej cisárskej provincie Judsko. Spoločne s manželkou sa usadili v prístavnom meste Cézarea, ned’aleko Jeruzalema. Pilát velil piatim pechotám a tiež jazdeckému pluku. Ako prefekt udržiaval poriadok a dohliadal na výber daní. ${ }^{101}$ So židovským l’udom zaobchádzal mimoriadne arogantne. Krátko po nástupe do úradu dal dopravit’ do Jeruzalema cisárske obrazy (signa), umiestnené na zástavách a štandardách vojska. Týmto krokom pobúril mestské i vidiecke obyvatelstvo. Aj napriek žiadostiam, aby obrazy odniesli preč, Pilát neustúpil. Dokonca privolal vojakov so zbraňami, aby potrestali Židov.

Zásadným mílnikom v jeho živote je súdenie a poprava Ježiša Krista. Nakol'ko židovský lud spadal pod jurisdikciu Rímskej ríše, musel predstúpit’ pred Piláta a požiadat’ ho, aby odsúdil Krista na smrt'. Pilát nevidel na Ježišovi žiadnu vinu a chcel mu dat v súvislosti s nadchádzajúcim sviatkom Pesach milost'. Ponúkol ludu možnost' vol'by - oslobodí Ježiša Krista alebo druhého odsúdeného - Barabáša. Zhromaždený dav však žiadal prepustit’ Barabáša (Lk 23: 5 - 19). ${ }^{102}$ Pilát sa opät’ pokúsil presvedčit’ zástup o nevine Ježiša Krista: „Priviedli ste ku mne tohto človeka, že podnecuje ludí k vzbure, a hla, vypočul som ho pred vami, ale nenašiel som na tomto človeku žiaden dôvod na obvinenie, ktoré proti nemu vznášate. Ba ani Herodes, lebo nám ho poslal spät'. A hla, nedopustil sa ničoho, čo si zasluhuje smrt'. Preto ho potrestám a prepustím." Ale ludia sa domáhali Ježišovej smrti, až im napokon Pilát vyhovel. Prepustil Barabáša, väzňa, ktorý bol odsúdený za poburovanie a vraždu, a odovzdal im Ježiša, aby s ním urobili, 
čo chcú. Vzal vodu, umyl si pred zástupom ruky a vyhlásil: „Ja nemám vinu na krvi tohto človeka. To je vaša vec!"103

Poslednou zaznamenanou etapou Pilátovho života bol d’alší konflikt. Po tom, čo okolo roku 36 napadol Samaritánov na hore Gerizim, bol Židmi nahlásený sýrskemu prefektovi Vitelliovi, ktorý docielil u cisára jeho odvolanie. ${ }^{104}$ Ďalej sa o Pilátovi dozvedáme už len z apokryfov a legiend, nie z historických prameňov. Niektoré uvádzajú, že sa stal krest’anom, podla iných spáchal samovraždu ako Judáš Iškariotský. Čo sa skutočne s Pilátom stalo, zostáva i nad'alej predmetom dohadov. ${ }^{105}$

\section{Pilát v rockovej opere Jesus Christ Superstar}

S Pilátom sa diváci v diele Jesus Christ Superstar stretávajú ovela skôr, ako sa stane klúčovou postavou príbehu. Prvýkrát sa objavuje potom, čo Ježiš a jeho nasledovníci prichádzajú do mesta Jeruzalem. V ten deň má Pilát sen, ktorý odhaluje zvyšok Ježišovho života, jeho smrt' a rozvíjajúce sa dejiny krestananstva až do modernej doby. ${ }^{106}$ Tvorcovia pri formovaní Pilátovho charakteru vychádzali prevažne z evanjelií. Podobná je i informácia o zlých snoch, ktoré sa podla Biblie nesnívali Pilátovi, ale jeho žene. Zaujímavé je, že tvorcovia nevykreslili Piláta ako krutého vládcu, ale ako empatického človeka so vznešeným duchom. Identicky spracovali aj čast' Pilátov súd, v ktorej sfanatizovaný dav spoločne s vel'kňazom Kaifášom žiada Ježišovu smrt'. Rovnako ako Judáš, aj Pilát sa v tomto príbehu ocitol v situácii, ktorá nie je výhodná. Sám nevidel dôvod na to, aby poslal Ježiša na smrt'. Avšak po obrovskom nátlaku ludí a Kaifášovej poznámke: „We need him Crucified, It's all you have to do.' ${ }^{107}$ [Ty nám ho ukrižuj! To žiada si náš lud.] ${ }^{108}$ už cítil, ako ho všetci tlačia k múru. Napriek tomu, že sa mu to priečilo, nechal Krista zbičovat' - „... to keep you Vultures happy.... ${ }^{109}$ [Tu pre výstrahu stačí bičovanie!], ${ }^{110}$ aby uspokojil rozvášnený dav. Pilát v sebe viedol vnútorný boj. Nechcel dopustit', aby sa stal bábkou bez názoru, a preto ešte raz vyzval Ježiša, aby prehovoril: „Why do you not speak when I hold your life in my hands? $?^{\prime 11}$ [Tak prečo len mlčíš? Mám v rukách tvoj život.]. ${ }^{112} \mathrm{~V}$ tejto intímnej chvíli Ježiš Pilátovi odvetil, že nie je v jeho silách niečo zmenit. Po nátlaku davu Pilát rezignoval a odsúdil Ježiša na smrt'. Teatrálne si zmyl ruky, aby odsunul pozornost' od vlastnej bezmocnosti a zachoval si tak hrdý odchod. Zároveň to bol aj symbol zmytia zodpovednosti za Ježišovu smrt'.

\section{Herodes Antipas}

Herodes Antipas (20 pred n. I. - po 39 n. I.) bol židovský tetrarcha a vládca palestínskych provincií. V súčasnosti je známy predovšetkým vd’aka Novému zákonu a udalostiam spojeným s popravou Jána Krstitela a Ježiša Krista. Herodes bol v poradí siedmym synom Herodesa I. (Vel'kého), ktorý mal desat' manželiek. Jeho matka Malthaké pochádzala zo Samárie. Spoločne s bratom Herodesom Archelaom vyrastal v Ríme. Neskôr sa stal korunným princom namiesto najstaršieho syna Herodesa I. - popraveného Herodesa Antipatra. Po otcovej smrti mu cisár Augustus udelil vládu nad židovskými provinciami Galilea a Parea. Krátko na to sa oženil s dcérou krála Aretasa IV. ${ }^{113}$ Ako vládca pokračoval v otcovom poslaní. Vybudoval pevnost' Betramta a mesto Tiberias na brehu Genezaretského jazera. ${ }^{114}$ Pod jeho správu patrili prístavy, cesty, bane, lesy, pol'nohospodárska pôda a rybárske oblasti. Herodesovi poddaní museli financovat' jeho nákladný život, stavebné projekty, zložitú štátnu správu a rôzne dotácie, ktoré 
udeloval svojim známym a mestám. ${ }^{115}$ Napriek mnohým snahám sa Herodesovi nepodarilo získat’ náklonnost' cisára Augusta. Avšak to, čo nedosiahol u neho, dosiahol u jeho nástupcu, cisára Tiberia, ktorého informoval o všetkých politických aférach. ${ }^{116}$ Počas jednej cesty do Ríma navštívil svojho nevlastného brata Herodesa Boetha (Herodes Filip) a zalúbil sa do jeho manželky Herodias. Po návrate vyhnal svoju zákonitú manželku a žil v hriešnom manželstve s Herodiadou. Boží služobník Ján Krstitel' verejne kritizoval Herodesovo manželstvo a upozorňoval ho, že to, čo urobil, nebolo správne. Herodesovi sa Jánove slová nepáčili, a tak ho dal uväznit.. ${ }^{17}$ Po čase Herodes slávil narodeniny. Usporiadal vel'kú hostinu pre svojich dvoranov, vojenských velitelov a významné osobnosti Galiley. Herodiadina dcéra začala pred hostami tancovat'. Jej pôvabný tanec sa všetkým vel’mi páčil a Herodes sa rozhodol dat' jej zvláštny dar. Povedal: „O čokolvek ma požiadaš, to ti dám, až do polovice svojho královstva." Na podnet Herodiady si vyžiadala st’atú hlavu Jána Krstitela. Hoci to Herodesa zarmútilo, nechcel jej žiadost’ odmietnut’ pre prísahu, ktorú vyslovil pred hostami. Vedel, že Ján je spravodlivý a svätý muž, ale dal slub a bál sa, čo by si ostatní pomysleli, ak by svoje slovo nedodržal. A tak poslal do väzenia telesného strážcu a rozkázal mu, aby Jánovi staal hlavu. ${ }^{118}$ Potom, čo Herodes popravil Jána Krstitela, dozvedel sa o zázračných skutkoch Ježiša Krista. Obával sa silnejúcej moci prorokov a v Ježišovi videl Jánovho nástupcu. Podla Lukášovho evanjelia sa Herodes stretol s Ježišom, ked' Pilát zistil, že je Galilejčan. Herodes dúfal, že uvidí Ježiša urobit’ nejaký zázrak. Ježiš však odmietol uspokojit’ Herodesovu zvedavost'. Sklamaný Herodes a jeho stráž začali Ježiša zosmiešňovat'. Obliekli ho do král'ovských šiat a poslali naspät’ k Pilátovi. V ten deň sa zlepšili vzt’ahy medzi Pilátom a Herodesom napriek ich predošlému nepriatel'stvu (Lk 23: 5 - 12). ${ }^{119}$ Herodes prežil zvyšok svojho života v exile. Rímsky cisár Caligula ho po židovskej st’ažnosti vyhostil do Lyonu, kde zomrel. ${ }^{120}$

\section{Herodes v rockovej opere Jesus Christ Superstar}

Herodes Antipas bol v rockovej opere Jesus Christ Superstar predstavený ako galilejský král.' Objavil sa v druhom dejstve v scéne pred Ježišovým ukrižovaním. Jeho výstup sa začína potom, ako rozvášnený dav na základe Kaifášových obvinení žiada Ježišovu smrt'. Vyhlásit’ rozsudok mal rímsky prefekt Pilát, ten však vložil Ježišov osud do rúk Herodesa, pretože mu ako galilejskému král'ovi prislúchala právomoc vykonat’ tento súd. ${ }^{121}$ Herodes sa na Ježiša doslova tešil, vel'a o ňom počul a prial si, aby sa stretli. Pred Ježišom sa Herodes správal mimoriadne okázalo a teatrálne, dokonca ho podpichoval a žiadal, aby dokázal svoju božskost’ a predviedol mu hocijaký zázrak. Vyzýval ho slovami: „Prove to me that you're divine / Change my water into wine ${ }^{\prime 122}$ [Ak si Kristus, ak si ten / Na víno mi vodu zmeň"] ${ }^{123}$, "Prove to me that you're no fool / Walk across my swimming pool'124 [Prejdi, Kristus, ak si ten / Suchou nohou cez bazén!"]. ${ }^{125}$ Ježišovo mlčanie Heroda rozzúrilo, a kedže mu Ježiš nedokázal svoju výnimočnost', poslal ho spät k Pilátovi ${ }^{126}$ ako d’alšieho falošného mesiáša, ktorý zo seba robí len blázna.

Herodes bol zobrazený ako bohatý člen šlachty, vel'mi cynický človek, ktorý si uvedomoval svoju silu. Jeho počiatočne sympatizovanie s Ježišom sa skončilo hnevom, čo poukazovalo na fakt, že okrem priatel'skej a vl'údnej povahy mal tiež schopnost’ správat’ sa ako bezohladný vládca. Ježiš sa pre neho stal d’alším bezvýznamným človekom, ktorý sa na chvílu ocitol v pozícii celebrity, vd’aka spochybňovaniu hodnôt spoločnosti. ${ }^{127}$ 
Režisér O'Horgan v prvom divadelnom uvedení predstavenia Jesus Christ Superstar (New York, 1971) niektoré charaktery postáv značne nadsadil, čo vplývalo aj na ich výsledné predvedenie a na vznik mnohých nepriaznivých kritík. Herecké stvárnenie krála Herodesa (Paula Ainsleyho) si v novinách viacnásobne vyslúžilo označenie „drag queen". 128

\section{Hudobná charakteristika diela a jeho predohra}

Rockovú operu Jesus Christ Superstar možno charakterizovat’ ako netradičné, zvukovo a žánrovo pestré dielo, ktoré spája prvky artificiálnej a nonartificiálnej hudby. Aj preto si získalo vel'ké množstvo nadšencov rôznych vekových kategórií a hudobno-štýlových preferencií. Sám Lloyd Webber tvrdil, že rock má neobmedzenú definíciu a priznal, že jeho hudba je eklektická, ovplyvnená Igorom Stravinským či Billom Haleyom. ${ }^{129}$ Niektorí hudobní kritici však tvrdia, že jednotlivé melódie diela sú do značnej miery ovplyvnené aj G. Bizetom, J. S. Bachom či L. Bernsteinom. Najdominantejším prvkom celého diela je motivicko-melodická práca. Jednotlivé motívy charakterizujú postavy, situácie, miesta či myšlienky. Typickým znakom hudby Jesus Christ Superstar sú bohaté melódie vokálnych a zborových partov, časté zmeny metra, ktoré ovplyvňujú rytmus jednotlivých skladieb, striedanie tonality a modality. Harmónia je teda rozmanitá. V niektorých momentoch jednoduchá, avšak vo vypätých situáciách príliš zložitá spomenút' možno moment ukrižovania Ježiša Krista, ked' autor intenzívne pracuje s disonanciou, chromatikou a klastrami, ktoré zaznievajú vo všetkých nástrojoch. Charakteristické je tiež využitie rozličných štýlovo-žánrových oblastí, v diele zaznievajú hudobné prvky vážnej hudby, chorálu, rocku, folku, gospelu, vaudevillu či elektronickej hudby, čo prispieva k väčšej výrazovej pestrosti diela. Vdłaka tomu mohol Lloyd Webber využit širokú škálu hudobno-výrazových prostriedkov pri zhudobňovaní jednotlivých postáv a navodzovaní konkrétnych dramatických situácií.

Rockovú operu otvára Ouverture, ktorá je neodmyslitel'nou súčastou operného diela už od jeho zrodu. Poslucháča sprevádza základnými náladami diela a melódiami najznámejších árií. Lloyd Webber tu predstaví takmer všetky hlavné motívy (okrem motívu Ježiša a Márie Magdalény) - motív súdu (interpretovaný elektronickou sólovou gitarou), motív rozsudku, motív Ježiš pred Pilátom (v ktorom prvýkrát zaznievajú dychové nástroje) a d’alšie motívy: Ježišova obrana, Rozsudok davu, motív Judáša (ktorý je rockovým riffom v ostinate), oslavný motív Superstar a na záver motív Judášovej smrti (pozri Prílohu). ${ }^{130}$ Napriek tomu, že predohra sa začína a končí v 4/4 metre, je charakteristická častou zmenou metra: prejde ňou až šest'krát, a to konkrétne v 4/4, 3/4, 5/8, 6/8, 7/8 a 2/4 metre. Jednotlivé zmeny sú pritom často rýchle - niekedy nastávajú už po jednom takte.

Príklad 1: Časté zmeny metra v predohre ${ }^{131}$

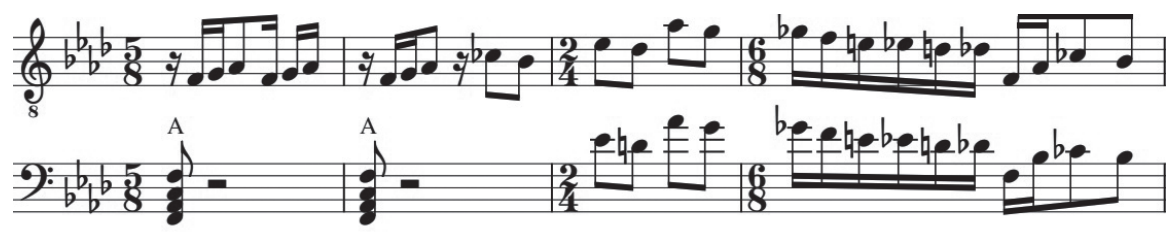


Tempové označenia sa zmenia sedemkrát: predohra sa začína v tempe Andante, nasleduje Agitato, L'istesso tempo, Animoso - Double Time, Subito, Adagio ma non troppo, Maestoso e Grandioso, a poslednou zmenou je tempo Subito e misterioso. Aj harmónia disponuje pestrou škálou zložitých harmonických postupov a modulácií do príbuzných, ale aj vzdialených tónin: začína tónina d mol, nasleduje f mol, d’alej prechádza cez C dur, B dur, H dur, F dur, As dur, Es dur, A dur, d mol, C dur, B dur, $\mathrm{H}$ dur, F dur, As dur, Es dur, D dur, a končí v tónine G dur. Treba však poznamenat', že mnoho úsekov ouvertúry je tonálne neukotvených a sú plné chromatických postupov. Operná predohra tak poslucháčovi skutočne napovedá, že ide o pestré dielo, plné metrických, tempových, harmonických zmien, nádherných melódií či zložitých rytmov.

Neodmyslitel'nou súčastou diela je zbor. Zborové party sú hudobne nenáročné, často zaznievajú v unisone. Náročnejší zborový part sa objaví až v oslavnej piesni Hossana, ktorá poslucháča okúzli harmonickou vynaliezavostou. Začína v G dur, potom vybočí do tóniny Es dur, es mol, e mol, c mol, As dur, D dur a na záver opät’ zaznieva G dur.

\section{Ježiš}

Hlasové zaradenie Ježiša je tenor. Rozsah jeho vokálnych partov je $h-c^{3}$, čo dokazuje, že interpretácia tejto postavy si vyžaduje maximálnu technickú pripravenost'. Najvýraznejším výstupom Ježiša a zároveň tým, čo ho v priebehu rockovej opery charakterizuje najviac, je pieseň Getsemanská záhrada - I only want to say. V tomto momente je Ježiš v Getsemanskej záhrade úplne sám, zatial' čo všetci apoštoli spia. Pieseň je jeho modlitbou, rozhovorom s Bohom. Pieseň symbolizuje Ježišovo zúfalstvo, úzkost', strach a pochybnosti. Popredná americká psychologička Elisabeth Kübler-Rossová vydala v roku 1969 jednu z najslávnejších psychologických štúdií pod názvom O smrti a umieraní. V rámci nej poukazuje na pät fáz smútku, ktoré spája so smrtou/ umieraním - popieranie, hnev, vyjednávanie, depresia a akceptácia. ${ }^{132}$ Ak sa bližšie pozrieme na text tejto piesne zistíme, že aj Ježiš prechádza týmito fázami. V úvodných taktoch Ježiš prechádza fázou zapierania, vyslovuje: „Take this cup away from me, for I don't want to taste its poison. Feel it burn me I have changed", 133 [Tento kalich z rúk mi vezmi, je v ňom smrt’ a tá ma väzní. S neistotou zápasím, už nie som tým, kým bol som predtým]. ${ }^{134}$ Nasleduje fáza hnevu: „Listen, surely I've exceeded expectations. Tried for three years, seems like thirty. Could you ask as much from any other man?"135 [Tie tri roky tažké boli, dnes ma chorá duša bolí. Čakám na pár tvojich viet: to mieniš mňa vziat' za obet'?] ${ }^{136}$. Po hneve prichádza fáza vyjednávania: „Oh why should I die? Can you show me now that I would not be killed in vain? Show me just a little of your omnipresent brain. Show me there's a reason for your wanting me to die."137 [Myslíš, ak ma vydáš smrti, že ma pochopia? Moje slová, moje skutky, budú vážit' viac?]. ${ }^{138}$ Predposlednou fázou Ježišovho smútku je etapa depresie: "Now, I'm sad and tired. After all, I've tried for three years, seems like ninety. Why then am I scared to finish what I started"139 [Pane, som sám; Pane, strach mám, Ty vieš! ... Sám, sám umriet’ mám. Záchranu nečakám. Kráčam v tmách. Spásu nečakám.] ]40 Poslednou fázou je akceptácia: „God, thy will is hard. But you hold every card. I will drink your cup of poison. Nail me to your cross and break me. Bleed me, beat me. Kill me." ${ }^{\prime 41}$ [Porúčam sa tvojej vôli. Ako povieš, tak to bude, aj ked'je to zlé a kruté.] ${ }^{142}$ 
V rámci piesne sa, vzhl'adom na emocionálny text, kladie dôraz na precítený spev - autor necháva spevákovi otvorený priestor interpretovat’ pieseň podla vlastných predstáv, často v nej možno nájst’ označenie ad libitum (celkovo v jeho vokálnych partoch, nielen v rámci tejto piesne). Len výnimočne autor predpisuje dynamické a výrazové označenia. Zvolené hudobnovýrazové prostriedky sú tak prispôsobené textu. Ježišova prvá fáza smútku, zapieranie, je sprevádzaná len akustickou gitarou. Napriek jednoduchej inštrumentácii je harmónia bohatá, založená na neustálom striedaní akordov - $B^{b} m, E^{b} m, A^{b}, D^{b}, F^{7}, G^{b 7}, C^{7}, B^{b 7}, E^{b}, G^{b}, C m, B^{b}, G$. V tejto belkantovej melódii nemožno nájst' väčšie intervalové skoky: je postavená na intervaloch sekundy a tercie. Vo fáze hnevu sa ku gitare pridávajú bicie a sláčikové nástroje, dynamika postupne narastá. Najexpresívnejšie zhudobnená fáza tejto piesne je etapa depresie. Expresívnejšia začína byt’ aj inštrumentácia - pridávajú sa aj dychové nástroje, bicie nástroje sú intenzívnejšie a dynamika čoraz viac graduje. Melodika je v tejto časti postavená na väčších intervalových skokoch. Napriek tomu, že väčšina piesne je zapísaná v 4/4 metre, prichádza zmena a nastupuje 2/2 metrum, ktoré však trvá len 16 taktov, potom sa opät' navracia 4/4 metrum. Po tejto metrickej zmene prichádza intervalový skok $e^{2}$ $-c^{3}$. Tento „výkrik" prichádza zo slovami "Why should I die?" "143 [Sám zomriet' mám]. ${ }^{144}$ To u poslucháča môže evokovat’ zúfalý nárek, hnev či strach. Ďalší výkrik, o niečo hysterickejší a expresívnejší, prichádza len o 12 taktov neskôr so slovami „Alright, I'll die. Just watch me die ${ }^{\prime \prime 145}$ [Sám, sám zomriet' mám.], ${ }^{146}$ pričom aj partitúra predpisuje výrazové označenie Ad lib hysterical sobbing.

Príklad 2: Výrazové označenie Ad lib hysterical sobbing v piesni Getsemanská záhrada ${ }^{147}$

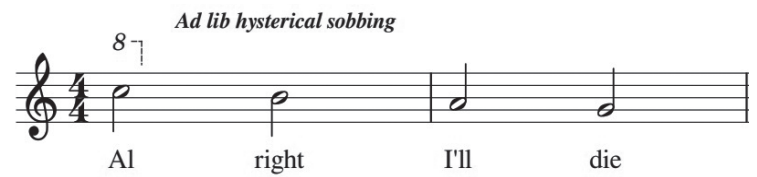

To nás utvrdzuje v tom, že Ježiš sa skutočne bojí, je vystrašený a nahnevaný. Prichádza desatttaktová grandiózna inštrumentálna medzihra v 5/8 metre, v ktorej dominujú dychové nástroje. Následne sa hudba úplne utíši a nastupuje fáza zmierenia. Teraz spev sprevádza len zvuk klavíra, inštrumentácia tak opätovne necháva vyzniet’ spev a Ježiš prijíma svoj osud. Zmierený so svojou smrtou prosí Boha, aby umučil jeho už aj tak bezmocné telo. Opät’ sa pridávajú sláčikové a dychové nástroje. Harmónia je zrazu plná disonancií - objavujú sa v nej malé sekundy a zväčšená kvarta, čo u poslucháča môže vyvolat' pocit hrôzy. Posledná fráza Ježiša „Kill me. Take me now! Before I change my mind! "148 [Umučte to telo bezmocné, kým nezakričím nie!] ${ }^{149}$ sa končí tónom $g^{2}$. Takýto výkrik a disonantné ukončenie piesne môže znamenat', že Ježiš sa so svojou obetou úplne nezmieril, ale prijíma ju preto, aby vykúpil svoj lud od hriechu a aby zostal verný Bohu aj v najtaž̌ších skúškach.

Najemotívnejšou čast’ou celej rockovej opery je Ježišovo ukrižovanie. Autor využíva rôzne zvuky, ba dokonca až hluky - údery kladiva, bicie nástroje, klastre, glissandá dychových nástrojov, ktoré sa miešajú s Ježišovými výkrikmi a d’alšími hlasmi. Celkový zvuk môže pripomínat' hudbu timbru, napríklad Pendereckého. ${ }^{150}$ Nasleduje záverečná katarzia, túto emotívnu čast' interpretuje symfonický orchester, poslucháčovi môže pripomínat' hudbu romantizmu, ktorá je plná emócií. 


\section{Mária Magdaléna}

Pre jej postavu skladatel' zvolil mezzosoprán. Tónový rozsah jej jednotlivých melódií je $f-c^{2}$. Ak hovoríme, že dielo Jesus Christ Superstar je plné harmonických, tempových či metrických zmien, disonancií a chromatiky, v prípade zhudobnenia postavy Márie Magdalény to neplatí. Práve ona vnáša do tejto "drsnej" hudby kontrast v podobe lyrickosti. Jej jednotlivé hudobné výstupy majú folkový charakter a väčšinou sú postavené na striedaní hlavných harmonických funkcií. Najvýraznejším sólovým momentom Márie Magdalény je nepochybne skladba I don't know how to love him [Chcem hriat ta svojou láskou]. ${ }^{151}$ Ide o lyrickú uspávanku v ustálenom 4/4 metre. Tektonická výstavba skladby by sa dala priradit k populárnej piesni, čomu zodpovedá aj nástroj, ktorý je $v$ rámci tohto sprievodu dominantný - akustická gitara. Skladba je skomponovaná $v$ tónine $D$ dur, pričom nedochádza k moduláciám do vzdialených tónin. Jej forma je jednoduchá, možno ju vyjadrit' schémou AABABA.

Vokálny part úvodných taktov skladby môže u poslucháča evokovat prirodzený spád reči vo vyhrotených a zúfalých situáciách, ked' každá koncovka frázy melodicky klesá, čo zodpovedá charakteru skladby: je predsa vyjadrením jej najhlbšieho konfliktu - má sa Ježišovi vyznat' zo svojich citov a požadovat' stále miesto po jeho boku, alebo byt" "len“ vernou a oddanou nasledovníčkou? Najvýraznejším momentom nielen tejto skladby, ale tiež výstupov Márie Magdalény všeobecne, je čast' "Should I bring him down? Should I scream and shout? Should I speak of love, let my feelings out? I never thought l'd come to this! What's it all about?"152 [Telo vraví ber, duša doplní, nemám na výber, v láske splyniem s ním. Duša je večná, túžba tiež! Viem, že ty to vieš]. ${ }^{153}$

Príklad 3: I don't know how to love him, t. 24 - 29. ${ }^{154}$
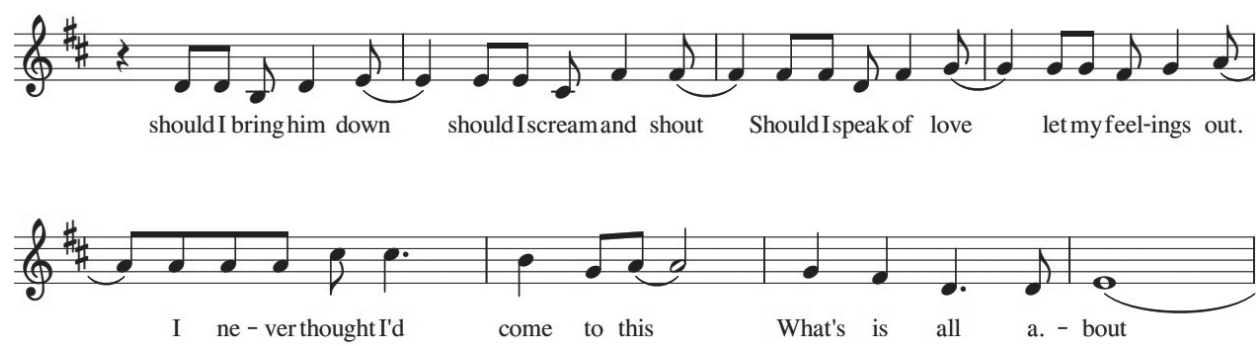

Táto čast' melodicky stúpa a dynamicky rastie, čo evokuje naliehavost', napätie, ale i vášeň hlavnej ženskej hrdinky, až vrcholí najvyšším tónom skladby $c^{2}$ vo forte. Tento moment umocňuje aj inštrumentácia, ked' sláčikové nástroje zdvojujú vokálnu melódiu, čo skladbe dodáva silu a energiu. Zaznieva akord C dur, čo môže vytvorit dojem, že skladba bude modulovat', avšak ked' dosiahne svoj vokálny vrchol, opät zaznieva akord $D$ dur a následne znovu prichádza verš. Hudba sa potom vracia k refrénu „Should I bring him down..." ${ }^{175}$, ale teraz sa spev pridáva až v časti "I never thought l'd come to this! What's it all about?"156 Tým sa vrchol piesne zopakuje, avšak s väčšou vášňou - so vzrastajúcim napätím sa pridávajú d’alšie nástroje, silu tohto momentu umocňuje aj dynamika vo forte-fortissimo. Skladba sa končí zopakovaním verša v tónine D dur a záverečnými slovami „, love him so"157 [Ja chcem byt’s ním.] ${ }^{158}$ 


\section{Judáš}

Pre Judáša zvolil autor tenor. Rozsah Judášových vokálnych partov je $h-e^{3}$. Táto postava spolu s Ježišom patrí medzi najnáročnejšie postavy, a to nielen požiadavkou na hodnovernú hereckú akciu, ale tiež prepracovanú spevácku techniku. Väčšina Judášových výstupov je výrazne rocková, a preto sa kladie dôraz na expresívny spev a rockovú farbu hlasu interpreta. V jeho skladbách možno často nájst' aj tempové Moderato Rock-Tempo. Kedže sa príbeh rozpráva z pohladu Judáša, v priebehu rockovej opery má táto postava viacero významných momentov: Heaven on Their Minds, Judas' Death či Superstar. Pieseň Heaven on Their Minds [Už nie som zmámený159], zaznievajúca hned'po doznení predohry, predstavuje Judáša ako ústrednú postavu - inteligentného a vnímavého muža. Charakterizuje Judášov vztảh k Ježišovi. Judáš, predstavitel' kritického postoja, vníma Ježišovo posolstvo lásky ako priamu cestu k bolesti. To sa odzrkadluje aj v melodike piesne: tvrdé nasadenie hlasu, spev, ktorý miestami prechádza až do kriku a pentatonicky vedená melódia. Hudobne táto skladba prináša dôležitý element v podobe rockového riffu v ostinate: krátky motív interpretovaný sólovou elektrickou gitarou, ktorý je sprevádzaný basovou gitarou a bicími nástrojmi. Tento motív Judáša sa pravidelne vracia aj v priebehu diela.

Príklad 4: Motív Judáša - rockový riff' ${ }^{160}$

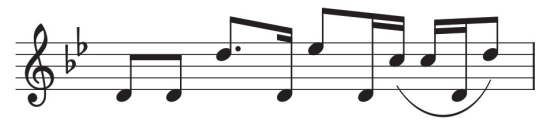

Jeden z najemotívnejších momentov celého diela je Judášova smrt', ktorá obsahuje fragment piesne I don't know how to love him. Prečo však autor hudby volí motív Márie Magdalény pri zhudobnení Judášovej smrti? Dá sa predpokladat', že to nemá byt' pripomienka na Máriu Magdalénu, ale na jej vernost’, oddanost’ a lásku k Ježišovi. Mária Magdaléna v piesni vyslovuje "I don't know how to love him, what to do, how to move him $^{\prime \prime 161}$ [Ach, ako ho mám lubit'?]. ${ }^{162}$ Tie isté pocity teraz má Judáš, vzápatí však opät' vyslovuje svoje pochybosti voči Ježišovi "He's a man, he's just a man. He's not a king, he's just the same ${ }^{\prime \prime 163}$ [Je to muž, nie je nič viac. Nie je Boh, či král'. Je len jeden z nás.]. ${ }^{164}$ Disonantná harmónia - intervaly malej sekundy a zväčšenej kvarty - umocňujú napätú atmosféru blížiacej sa smrti. Melodika tejto skladby je postavená na vel'kých intervalových skokoch, krátkych rytmických hodnotách nôt a tónov, ktoré siahajú až do trojčiarkovej oktávy - práve to môže u poslucháča evokovat’ krik, zúfalstvo a hystériu, ktorou Judáš prechádza.

Judáš obviňuje Ježiša zo svojej blížiacej sa smrti. Po týchto slovách opätovne zaznieva motív Judáša - vyššie spomínaný rockový riff, ktorý znie až do posledného výdychu Judáša. Vokálny part tejto časti je v partitúre označený výrazovým označením sobbing [vzlykajúci].

Príklad 5: Výrazové označenie sobbing v skladbe Judášova smrt' ${ }^{165}$

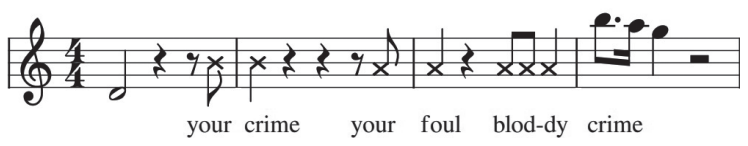




\section{Pilát}

Hlasovým zaradením je Pilát barytenor, pričom rozsah jeho piesní je $A-b^{1}$. Pilátova pieseň, Pilate's Dream, je predzvest’ou Ježišovho ukrižovania. Pilát sa budí zo sna a s hrôzou sa pýta, prečo ho má práve on odsúdit’ na smrt'. Podobne ako pieseň Márie Magdalény má aj táto folkový charakter. Ide o pieseň v jednoduchej forme, so sprievodom akustickej a basovej gitary. Harmónia vzniká striedaním hlavných harmonických funkcií. Čast' Ježiš pred Pilátom je však zhudobnená ovela expresívnejšie. Melodika tejto časti pozostáva z krátkych rytmických hodnôt, avšak nie z vel'kých intervalových krokov, často v nej zaznieva interval malej sekundy. Pilát preberá melódiu kňazov, čo možno chápat’ ako motív autority a moci. V harmónii zaznieva disonancia a inštrumentácia kladie dôraz na výrazné vstupy dychových nástrojov. Pilát požaduje, aby Ježiš všetko odvolal. Spomína na sen, ktorý mal. Necháva rozhodnút dav. Následne nechá Ježiša zbičovat’ 39 ranami a žiada ho, aby sa bránil. Dav je však neúprosný a žiada Ježišovu smrt'. Pilát vynáša rozhodnutie nad Ježišom, zmýva si ruky od krvi - on na jeho smrti netrval. V momente, ked' Pilát odratúva 39 úderov bičom, vracia sa motív Judáša - rockový riff interpretovaný elektrickou gitarou. Pod ním zaznievajú zhluky nástrojov, klastre a silné údery bicích nástrojov a zbor hlasno kričí „Ukrižuj ho!"166 Táto kombinácia môže u poslucháča evokovat’ pocity hrôzy, zdesenia a strachu zároveň.

\section{Herodes}

Ak sme na začiatku spomenuli, že Jesus Christ Superstar je kombináciou viacerých hudobných štýlov, nepochybne to platí aj o piesni krála Herodesa. Zábavná veselohra/ fraška so spevmi a tancami sa v divadelnom slovníku nazýva vaudeville. Práve k tomuto žánru môžeme prirovnat’ jedinú pieseň Krála Herodesa. Ide o satirickú pieseň vo forme ragtimu s jednoduchou, spevnou a l'ahko zapamätatel'nou melódiou, ktorá má oproti ostatným skladbám diela ovel’a menší rozsah $\left(a-g^{1}\right)$. Napriek tomu je postavená na bohatej harmónii - fis mol, D dur, A dur, Cis mol, h mol, E , H dur, fis ${ }^{7}, \mathrm{~h}$ mol, B dur, $\mathrm{C}^{7}$, G mol, Es dur, d mol, G dur. Tempo piesne sa zmení až devät'krát. Je to jediná humorná scéna celého diela, možno aj preto je u mnohých divákov oblúbená.

\section{Záver}

Jeden z najznámejších príbehov v histórii ludstva a hudba, ktorá vyvoláva zimomriavky. Aj tak možno zhodnotit' vel'kolepé a nadčasové dielo Andrewa Lloyda Webbera a Tima Ricea Jesus Christ Superstar, ktoré patrí k najoblúbenejším hudobnodramatickým dielam vôbec. Existuje Boh? Bol Ježiš skutočne synom Božím? Prečo Judáš zradil Ježiša? Miloval Ježiš Máriu Magdalénu láskou, akou muž miluje ženu? Prečo musel zakúsit’ tol'ko utrpenia? Prečo musel zomriet' na kríži? Aj takéto otázky vyvoláva tento príbeh. Veriaci žijú v presvedčení, že Boh poslal svojho syna Ježiša, aby na seba zobral všetky ich hriechy a plne za ne zaplatil svojou smrtou na kríži. Tým sa však príbeh nekončí. Ježiš totiž vstal z mŕtvych! Tým dokázal, že má moc nad životom a smrtoou. Môže právom slubovat' večný život a je jedinou cestou k Bohu. Ateisti toto učenie popierajú. Iní možno veria v niečo úplne iné. Jednotnú odpoved’ však nájst' nemožno. 
Dielo je hudobne spracované ako rocková opera. Je plné nádherných leitmotívov a melódií, zložitých, ale aj hybných rytmov. Dielo s vynaliezavou a farebnou harmóniou, precíznou inštrumentáciou, ktorá svojím zvukom poslucháča vt’ahuje do atmosféry jednotlivých dramatických situácií. Spojenie artificiálnych a nonartificiálnych hudobných prvkov predurčuje skladbu k úspechu. Nadšenci vážnej hudby, chorálu, modernej hudby - rocku, folku, vaudeville či elektronickej hudby, každý z nich si v určitej časti príde na svoje. Možno aj preto si dielo vyslúžilo zaznamenanie piesní na mnohých hudobných nosičoch, dve filmové spracovania $(1973,2000)$ a mnoho zaujímavých javiskových inscenácií po celom svete. Aj v súčasnosti ho možno nájst’ v repertoári početných svetových divadiel. Na slovenskej scéne bolo uvedené vo viacerých mestách - Bratislava, Ružomberok, Dolný Kubín, Tvrdošín, Záhorská Bystrica. Aktuálne toto dielo ponúka Divadlo Jonáša Záborského v Prešove.

\section{POZNÁMKY}

1 OSOLSOBĚ, Ivo: Marsyas, Apollón... a Dionýsos: Přibližování k muzikálu II. Brno: Divadelní fakulta JAMU, 1996, s. 12.

2 POLYÁKOVÁ, Marianna: Jesus Christ Superstar (Srovnání dvou inscenací). [Diplomová práca.] Brno: Janáčkova akademie múzických umění, 2017, s. 36.

3 BABOROVÁ, Kristýna: Jesus Christ Superstar: $k$ problematice historického zařazení, recepce a analýzy díla A. L. Webbera a T. Rice. [Diplomová práca.] Olomouc: Univerzita Palackého v Olomouci, 2017, s. 90 - 96.

4 BABOROVÁ, c. d., 2017, s. 40, 41.

5 POLYÁKOVÁ, c. d., 2017, s. 12 - 16.

6 PUMPRLOVÁ, Vendula: Andrew Lloyd Webber a jeho muzikálová tvorba. [Bakalárska práca.] Olomouc: Univerzita Palackého v Olomouci, 2012, s. 17.

POLYÁKOVÁ, c. d., 2017, s. 12 - 16.

BABOROVÁ, c. d., 2017, s. 30.

POLYÁKOVÁ, c. d., 2017, s. 12 - 16.

BABOROVÁ, c. d., 2017, s. 45.

BABOROVÁ, c. d., 2017, s. 41.

BABOROVÁ, c. d., 2017, s. $37-42$.

POLYÁKOVÁ, c. d., 2017, s. 12 - 16.

Preklad do slovenského jazyka Ján Štrasser. (Archív J. Štrasser.)

15 Tamtiež.

16 Tamtiež.

17 Tamtiež.

18 Tamtiež.

19 Tamtiež.

20 Tamtiež.

21 Tamtiež.

22 Tamtiež.

23 Tamtiež.

24 Tamtiež.
25 Tamtiež.

26 Tamtiež.

27 Tamtiež.

28 Tamtiež.

29 Tamtiež.

30 Tamtiež.

31 Tamtiež.

Tamtiež.

33 MAAS, Anthony: Origin of the Name of Jesus Christ. [Online.] New Advent, 1910. [Cit. 2021-08-06.] Dostupné na internete: https:// www.newadvent.org/cathen/08374x.htm

34 Kto je Ježiš Kristus. [Online.] In: Strážna veža, 2005. [Cit. 2021-08-06.] Dostupné na internete: https://wol.jw.org/sk/wol/d/r38/ lp-v/2011169

35 Mt 2: $1-12$

36 Mk 15: $1-15$

37 Mt 27: $50-54$.

38 Kto je Ježiš Kristus, c. d., 2005.

39 POLYÁKOVÁ, c. d., 2017, s. 8.

40 BABOROVÁ, c. d., 2017, s. $56-58$.

41 BABOROVÁ, c. d., 2017, s. $56-58$.

42 BABOROVÁ, c. d., 2017, s. 59.

43 LLOYD WEBBER, A. Lord: England: $\mathrm{Hal}$ Leonard. [Klavírny výtah.] 1985. [Online.] [Cit. 2021-08-20.] Dostupné na internete: https://musescore.com/amfem/jcs

44 Preklad do slovenského jazyka Ján Štrasser. (Archív J. Štrasser.)

45 PUMPRLOVÁ, c. d., 2012, s. 18.

46 SVOBODOVÁ, c. d., 2021, s. 16.

47 FORET, Miroslav: Jesus Christ Superstar a Ostatní Rockové Opery. Brno: Spolek Mojmír Akademického gymnázia, 1994, s. 24.

48 SARKA, Róbert: Teologické Akta X - kauza Judáš. [Online]. In: Teologické texty, 2010. 
[Cit. 2021-08-06.] Dostupné na internete: https://www.teologicketexty.cz/casopis/2010-2/Teologicke-Akta-X-kauza-Judas.html

49 TÓTH, Tihamér: Čomu nás učí Judášova zrada. [Online.] Christianitas, 2020. [Cit. 2021-08-06.] Dostupné na internete: https://www.christianitas.sk/comu-nas-uci-judasova-zrada-a-pad/

50 PÚČEK, Milan: Kto (vlastne) zradil Krista. [Online.] In: Denník N, 2020. [Cit. 202108-06.] Dostupné na internete: https:// dennikn.sk/blog/1836500/kto-vlastne-zradil-krista/

51 SARKA, c. d., 2010.

52 Naše cirkvi: Judáš bol zradca. [Online.] In: SME, 2006. [Cit. 2021-08-06.] Dostupné na internete: https://www.sme.sk/c/2667340/ nase-cirkvi-judas-bol-zradca.html

53 HIGDON, c. d., 2018.

54 ULIČIANSKA, c. d., 2014.

55 DRÁBEK, Václav: Modelové situace $v$ tematickém vyučování. A. L. Webber: Jesus Christ Superstar. In: Populární hudba a škola. Praha: Univerzita Karlova, 2000, s. 25.

70 Preklad do slovenského jazyka Ján Štrasser. (Archív J. Štrasser.)

71 BABOROVÁ, c. d., 2017, s. 57 - 59.

72 LLOYD WEBBER, c. d., 1985.

73 Preklad do slovenského jazyka Ján Štrasser. (Archív J. Štrasser.)

74 LLOYD WEBBER, c. d., 1985.

75 Preklad zo slovenského libreta od Jána Štrassera.

76 MILLER, Scott: Inside JESUS CHRIST SUPERSTAR. [Online.] In: New Line Theatre, [Cit.

2021-08-09.] Dostupné na internete: http:// www.newlinetheatre.com/jcschapter.html [Online.] 2018. [Cit. 2021-08-09]. Dostupné na internete: https://www.todaytix.com/ insider/chicago/posts/jo-lampert-on-modernizing-mary-magdalene-in-jesus-christ-superstar

FLATLEY, Guy: They wrote it - and they're glad. [Online.] In: New York Times, 1971. [Cit. 2021-08-09.] Dostupné na internete: https://www.nytimes.com/1971/10/31/ archives/they-wrote-it-and-theyre-glad-they-wrote-superstar.html (Archív J. Štrasser.)

Everything you need to know about Andrew Lloyd Webber's 'Jesus Christ Superstar'. [Online.] London Theatre, 2020. [Cit. 202108-09.] Dostupné na internete: https:// www.londontheatre.co.uk/theatre-news/ west-end-features/what-you-need-to-know-about-andrew-lloyd-webbers-jesus-christ-superstar

Characters / Jesus Christ Superstar. [Online.] Tvtropes. [Cit. 2021-08-09.] Dostupné na internete: https://tvtropes.org/pmwiki/ pmwiki.php/Characters/JesusChristSuperstar LLOYD WEBBER, c. d., 1985.

Preklad zo slovenského libreta od Jána Štrassera.

94 POLYÁKOVÁ, c. d., 2017, s. 28 - 36.

95 BABOROVÁ, c. d., 2017, s. $63-66$.

96 LLOYD WEBBER, c. d., 1985.

97 Preklad zo slovenského libreta od Jána Štrassera. 
SAVA, c. d., 2018

LATKOVICH, Sallie: Reclaiming Mary Magdalene in 'Jesus Christ Superstar'. [Online.] 2018. [Cit. 2021-08-09.] Dostupné na internete: https://www.chicagocatholic. com/other-authors/-/article/2018/04/25/ reclaiming-mary-magdalene-in-jesus-christ-superstar-

100 Kto bol Pontský Pilát? [Online.] In. Strážna veža, 2005. [Cit. 2021-08-06.] Dostupné na internete: https://wol.jw.org/sk/wol/d/r38/ Ip-v/2005683

101 VLADÁR, Vojtech: Proces s Ježišom Kristom pred Ponciom Pilátom podla rímskeho práva. In: Súdne reči a vel'ké súdne procesy. Trnava: Právnická fakulta Trnavskej univerzity v Trnave, 2010, s. $91-122$.

102 VALACHOVIČ, Pavol: Súdny proces, ktorý zmenil svet. [Online.] In: SME, 2019. [Cit. 2021-08-09.] Dostupné na internete: https://historickarevue.sme.sk/c/22528883/ sudny-proces-ktory-zmenil-svet.html

103 Lk 23: 13 - 25.

104 Pontius Pilate. [Online.] In: Encyclopaedia Britannica. [Cit. 2021-07-25.] Dostupné na internete: https://www.britannica.com/ biography/Pontius-Pilate

105 Kto bol Pontský Pilát?, c. d., 2005.

106 TILBORGH, c. d., 2020.

107 LLOYD WEBBER, c. d., 1985.

108 Preklad do slovenského jazyka Ján Štrasser. (Archív J. Štrasser.)

109 LLOYD WEBBER, c. d., 1985.

110 Preklad do slovenského jazyka Ján Štrasser. (Archív J. Štrasser.)

111 LLOYD WEBBER, c. d., 1985.

112 Preklad do slovenského jazyka Ján Štrasser. (Archív J. Štrasser.)

113 Herodes Antipas. [Online.] In: Encyclopaedia Beliana, 2008. [Cit. 2021-07-25.] Dostupné na internete: https://beliana.sav. sk/heslo/herodes-antipas

114 Biografia de Herodes Antipas. [Online.] In: Biografías y Vidas, 2004. [Cit. 2021-0725.] Dostupné na internete: https://www. biografiasyvidas.com/biografia/h/herodes_antipas.htm

115 Rybolov na Galilejskom mori. [Online.] In: Strážna veža, 2009. [Cit. 2021-07-25.] Dostupné na internete: https://www.jw.org/ sk/kniznica/casopisy/wp20091001/Rybolov-na-Galilejskom-mori/

116 Herodes vel'ký a jeho stavby. [Online.] In: Horčičné zrnko. [Cit. 2021-07-25.] Dostupné na internete: http://www.horcicnezrnko. sk/Svata\%20zem/Herodes\%20Velky.html

117 Lk 3:19, 20.

118 Mk 6: 22 - 29.
119 POBIJAK, Tomáš: Súdny proces s Ježišom Nazaretským. [Online.] In: lus et Societas, 2014. [Cit. 2021-07-25.] Dostupné na internete: http://www.iusetsocietas.cz/ fileadmin/user_upload/Vitezne_prace/ Pobijak_-_Sudny_proces_s_Jezisom_Nazaretskym.pdf

120 Whiston, William - AUBURN, A. M. - BEARDSLEY, John E.: The Works of Flavius Josephus. [Online.] In: Perseus, 1895. [Cit. 2021-07-25.] Dostupné na internete: http://www.perseus.tufts.edu/hopper/text?doc=Perseus:abo:tlg,0526,002:63\&lang=original

121 SVOBODOVÁ, c. d., 2021, s. 16.

122 LLOYD WEBBER, c. d., 1985.

123 Preklad do slovenského jazyka Ján Štrasser. (Archív J. Štrasser.)

124 LLOYD WEBBER, c. d., 1985.

125 Preklad do slovenského jazyka Ján Štrasser. (Archív J. Štrasser.)

126 POLYÁKOVÁ, c. d., 2017, s. 25.

127 HUDECOVÁ, Danuta: Transformations of Jesus Christ Superstar. [Diplomová práca.] Brno: Masarykova univerzita, 2015, s. 32 - 46.

128 „Drag queen“ je muž, ktorý sa prezlieka za ženu s ciel'om zabávania obecenstva, môže používat' oblečenie, parochňu a makeup. Kedže drag queens svoje správanie limitujú hlavne alebo výlučne v kontexte vystupovania, nie sú totožné s transsexuálmi a transvestitmi.

129 NASSOUR, Ellis, BRODERICK, Richard: Rock Opera: The Creation of Jesus Christ Superstar, from Record Album to Broadway Show and Motion Picture. New York: Hawthorn Books, 1973, s. 61.

130 BABOROVÁ, c. d., 2017, s. 90 - 97.

131 LLOYD WEBBER, c. d., 1985.

132 KONDÁŠ, Lucia: Elisabeth Kübler Ross: O smrti a umieraní, alebo čo by sa ludia mali naučit' od umierajúcich (recenzia). 2018. [Online.] [Cit. 2021-08-20.] Dostupné na internete: https://www.zomieranie.sk/n/ elisabeth-kuebler-ross-o-smrti-a-umierani-alebo-co-by-sa-ludia-mali-naucit-od-umierajucich-recenzia

133 LLOYD WEBBER, c. d., 1985.

134 Prekla Preklad do slovenského jazyka Ján Štrasser. (Archív J. Štrasser.)

135 LLOYD WEBBER, c. d., 1985.

136 Preklad do slovenského jazyka Ján Štrasser. (Archív J. Štrasser.)

137 LLOYD WEBBER, c. d., 1985.

138 Preklad do slovenského jazyka Ján Štrasser. (Archív J. Štrasser.)

139 LLOYD WEBBER, c. d., 1985.

140 Preklad do slovenského jazyka Ján Štrasser. (Archív J. Štrasser.) 
143 LLOYD WEBBER, c. d., 1985.

144 Preklad do slovenského jazyka Ján Štrasser. (Archív J. Štrasser.)

145 LLOYD WEBBER, c. d., 1985.

146 Preklad do slovenského jazyka Ján Štrasser. (Archív J. Štrasser.)

147 LLOYD WEBBER, c. d., 1985.

148 LLOYD WEBBER, c. d., 1985.

149 Preklad do slovenského jazyka Ján Štrasser. (Archív J. Štrasser.)

150 DRÁBEK, c. d., 2000, s. 28.

151 Preklad do slovenského jazyka Ján Štrasser. (Archív J. Štrasser.)

152 LLOYD WEBBER, c. d., 1985.

153 Preklad do slovenského jazyka Ján Štrasser. (Archív J. Štrasser.)
154 LLOYD WEBBER, c. d., 1985.

155 LLOYD WEBBER, c. d., 1985.

156 LLOYD WEBBER, c. d., 1985.

157 LLOYD WEBBER, c. d., 1985.

158 Preklad do slovenského jazyka Ján Štrasser. (Archív J. Štrasser.)

159 Preklad do slovenského jazyka Ján Štrasser. (Archív J. Štrasser.)

160 LLOYD WEBBER, c. d., 1985.

161 LLOYD WEBBER, c. d., 1985.

162 Preklad do slovenského jazyka Ján Štrasser. (Archív J. Štrasser.)

163 LLOYD WEBBER, c. d., 1985.

164 Preklad do slovenského jazyka Ján Štrasser. (Archív J. Štrasser.)

165 LLOYD WEBBER, c. d., 1985.

166 Preklad do slovenského jazyka Ján Štrasser. (Archív J. Štrasser.)

\section{SUMMARY}

A Music-psychological Profile of the Rock Opera Jesus Christ Superstar

The study focuses on the rock opera Jesus Christ Superstar written by the composer Andrew Lloyd Webber and librettist Tim Rice. In its first part the study deals with the circumstances of the origination of the work. The second part discusses the psychological description of its characters. It interprets the results of a comparison of characters of the original Biblical story with the rock opera libretto. In its closing part the contribution brings a brief description of the musical language of the work and the musical expressive means of its main characters.

\section{Keywords}

Jesus Christ Superstar; rock opera; main characters; psychological typology; musical characteristics 
NOTOVÁ PRÍlOHA

1. Motív súdu v Ouverture (t. 1 - 5)

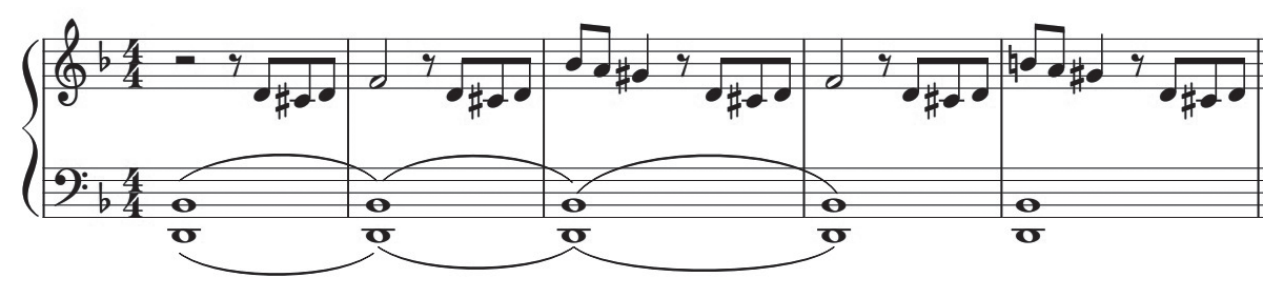

2. Motív rozsudku v Ouverture (t. 10 - 13)

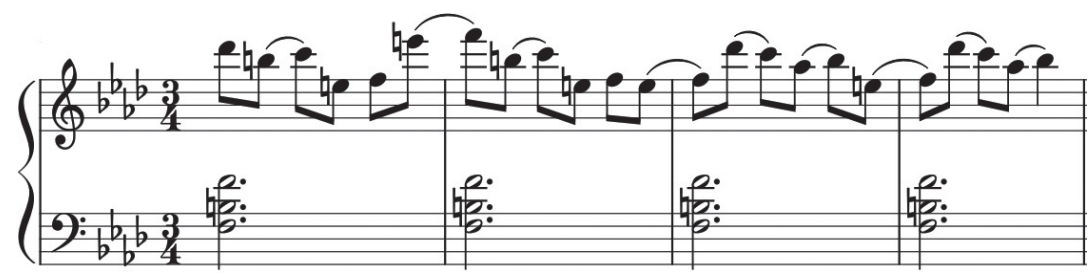

3. Motív - Ježiš pred Pilátom v Ouverture (t. 15 - 18)

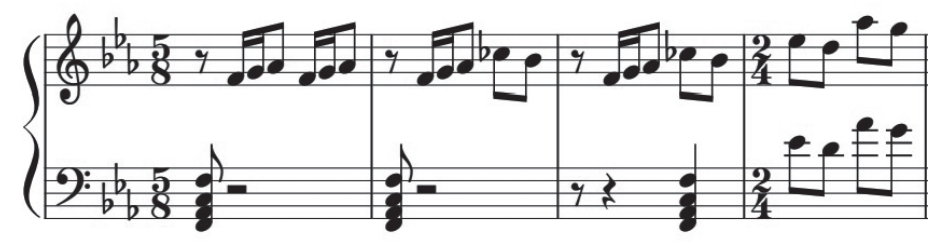

4. Motív - Ježišova obrana v Ouverture (t. 24 - 27)

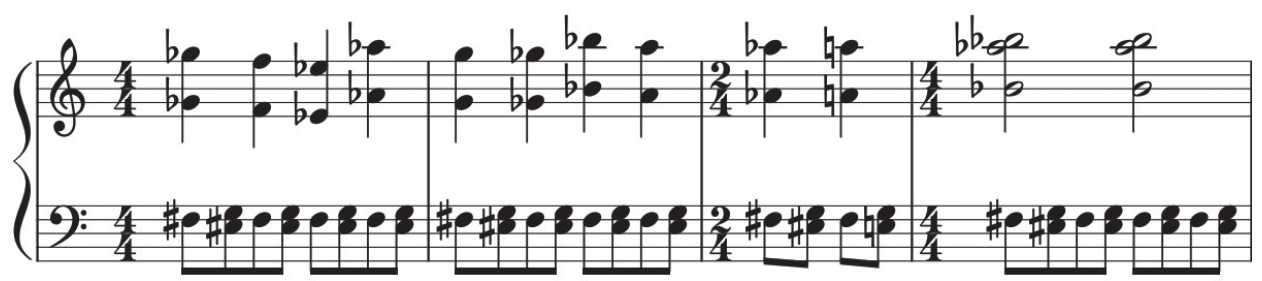


5. Motív - rozsudok davu v Ouverture (t. 53 - 58)
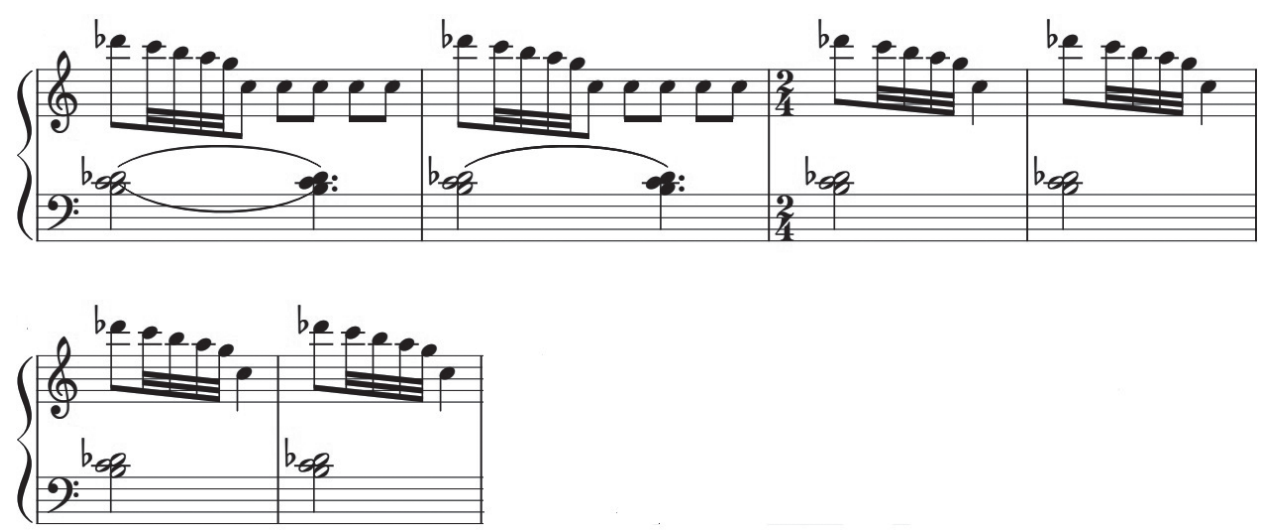

6. Motív Judáša v Ouverture (t. 71 - 72)

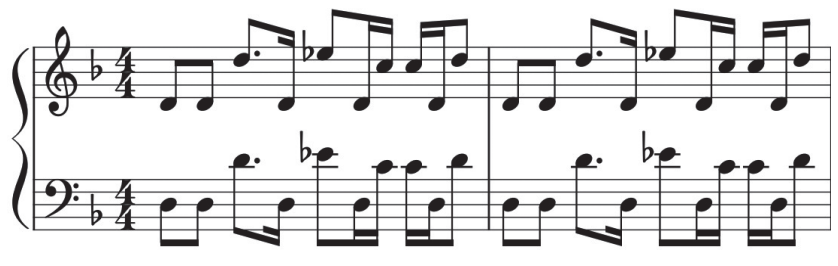

7. Motív - Pilát si umýva ruky v Ouverture (t. 98 - 101)

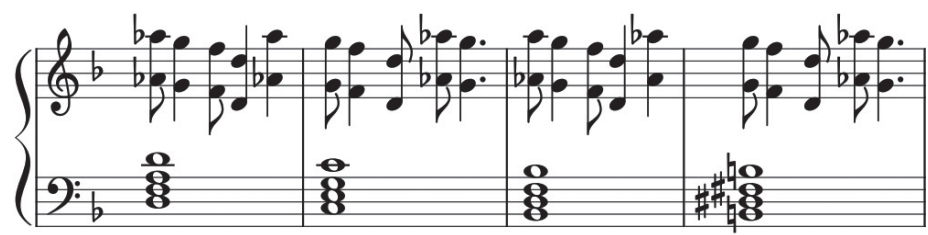

8. Motív Superstar v Ouverture (t. 106 - 108)

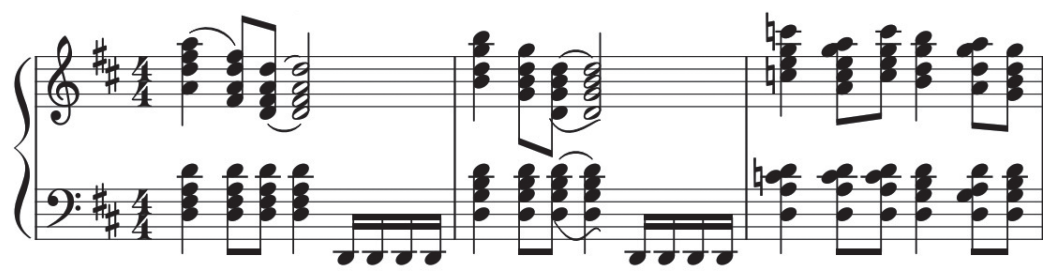


ŠTúDIE

9. Motív - Judášova smrt v Ouverture (t. 115 - 116)

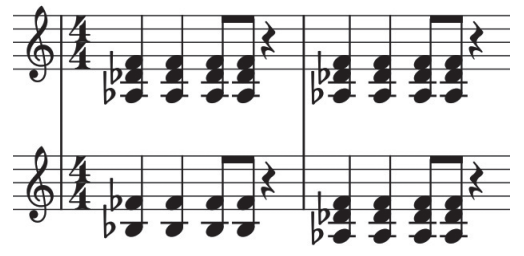

OBRAZOVÁ PRÍlOHA

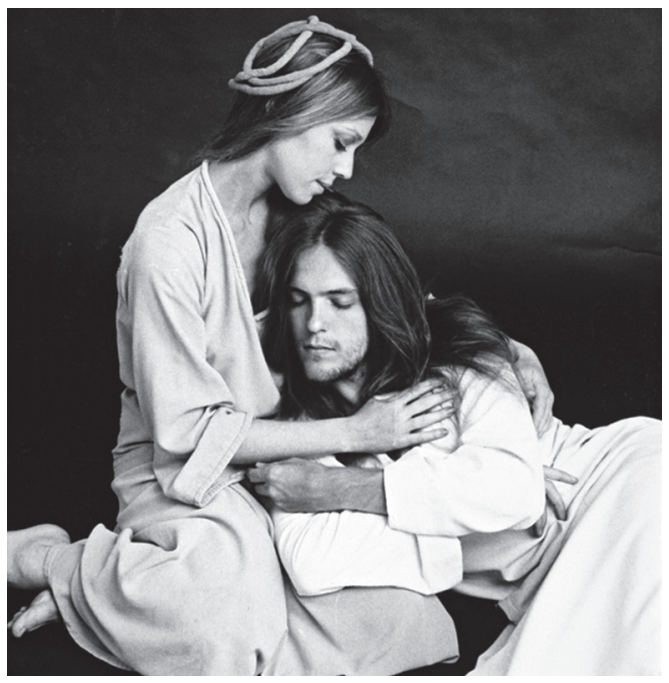

Obr. 1: Ježiš a Mária Magdaléna (prvé divadelné uvedenie, 1971), zdroj https://www.broadway. com/buzz/196870/jeff-fenholt-broadways-original-jesus-christ-superstar-dies-at-68/ 


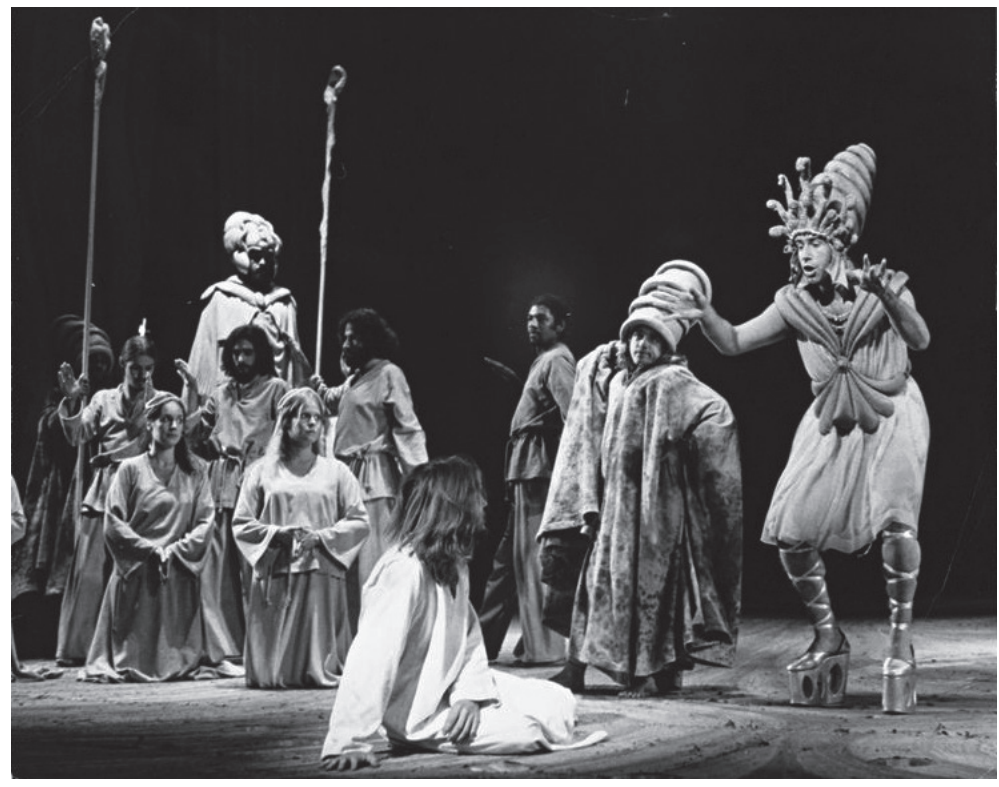

Obr. 2: Ježiš a Herodes (prvé divadelné uvedenie, 1971), zdroj https://www.pinterest.com/ pin/399061216959434795/

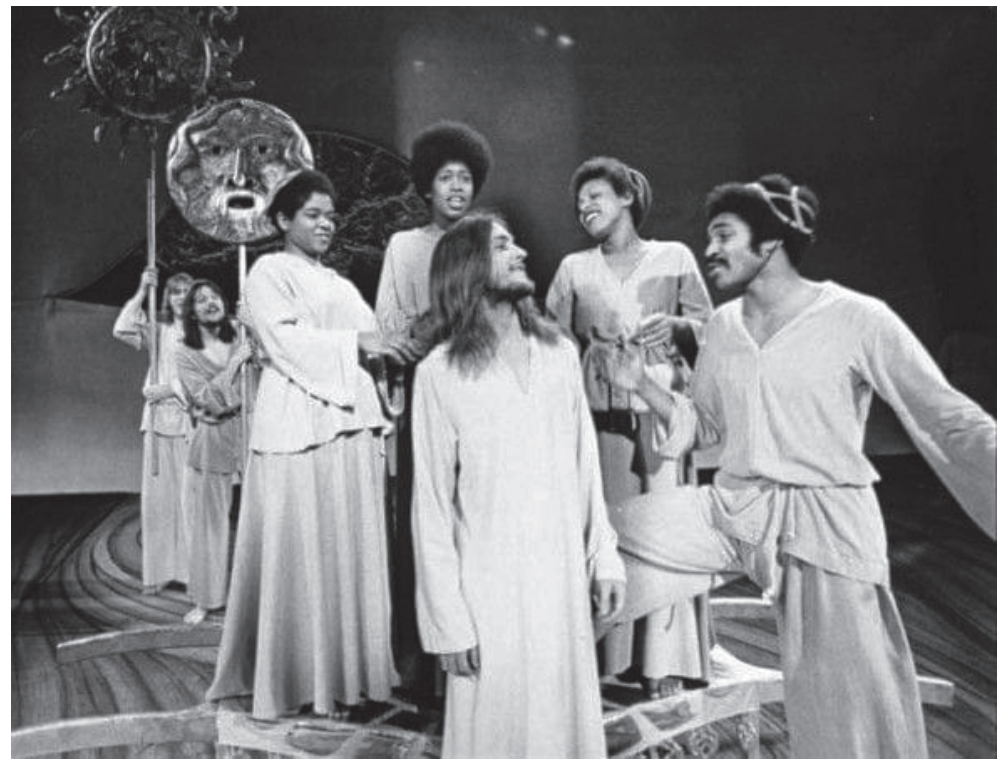

Obr. 3: Ježiš, Judáš a apoštoli (prvé divadelné uvedenie, 1971), zdroj https://www.playbill.com/ gallery/look-back-at-the-original-broadway-production-of-jesus-christ-superstar-on-broadway /?slide $=0$ 


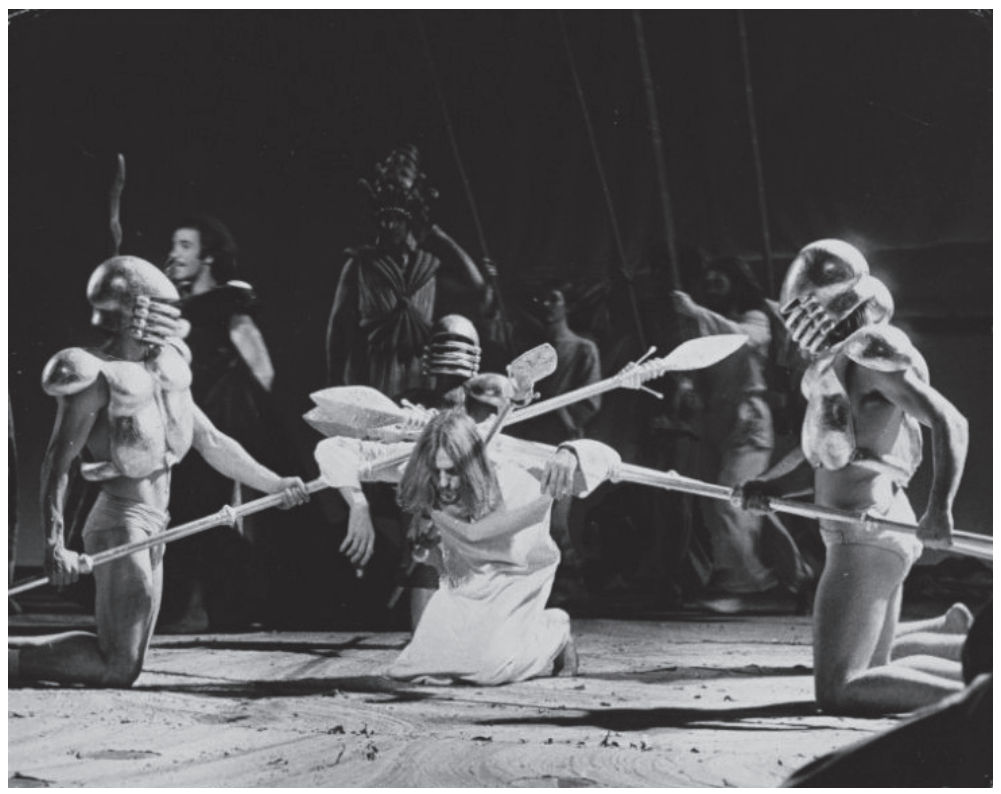

Obr. 4: Ježišovo zatknutie (prvé divadelné uvedenie, 1971), zdroj https://www.pinterest.com/ pin/399061216959434855/ 